medRxiv preprint doi: https://doi.org/10.1101/2021.11.06.21265967; this version posted November $8,2021$. The copyright holder for this preprint (which was not certified by peer review) is the author/funder, who has granted medRxiv a license to display the preprint in

All rights reserved. No reuse allowed without permission.

\title{
Immunogenicity of COVID-19 vaccines in patients with haematological malignancy: A systematic review and meta-analysis
}

Joanne S.K. Teh ${ }^{1,2}$, Julien Coussement ${ }^{1,2}$, Zoe C. F. Neoh ${ }^{1,2}$, Tim Spelman ${ }^{3}$, Smaro Lazarakis ${ }^{4}$, Monica A. Slavin ${ }^{1,2,5,6}$, Benjamin W. Teh ${ }^{1,2,5}$

${ }^{1}$ Department of Infectious Diseases, Peter MacCallum Cancer Centre, Melbourne, Victoria, Australia

${ }^{2}$ National Centre for Infections in Cancer, Peter MacCallum Cancer Centre, Melbourne, Victoria, Australia

${ }^{3}$ Department of Health Services Research, Peter MacCallum Cancer Centre, Melbourne, Victoria, Australia

${ }^{4}$ Health Sciences Library, Royal Melbourne Hospital, Parkville, Victoria, Australia

${ }^{5}$ Sir Peter MacCallum Department of Oncology, University of Melbourne, Parkville, Victoria, Australia

${ }^{6}$ Victorian Infectious Diseases Service, Royal Melbourne Hospital, Melbourne, Victoria, Australia

Primary contact:

A/Prof. Benjamin W. Teh

Department of Infectious Diseases,

Peter MacCallum Cancer Centre,

305 Grattan Street,

Melbourne 3000,

Victoria, Australia

Tel: +61385597994

Fax: +6138559 XXXX

Email: ben.teh@petermac.org

Keywords: COVID-19; vaccination; haematological; malignancy; immune response

Short title: COVID-19 vaccine response in haematology patients

Abstract length: 246 words

Manuscript length: 3997

Tables and figures: 4 tables, 3 figures

Supplementary appendix 
medRxiv preprint doi: https://doi.org/10.1101/2021.11.06.21265967; this version posted November 8, 2021. The copyright holder for this preprint (which was not certified by peer review) is the author/funder, who has granted medRxiv a license to display the preprint in

All rights reserved. No reuse allowed without permission.

\begin{abstract}
The objectives of this study were to assess the immunogenicity and safety of COVID-19 vaccines in patients with haematological malignancy. A systematic review and meta-analysis of clinical studies of immune responses to COVID-19 vaccination stratified by underlying malignancy and published from 1 January 2021 to 31 August 2021 was conducted using MEDLINE, EMBASE and CENTRAL. Primary outcome was the rate of seropositivity following 2 doses of COVID-19 vaccine with rates of seropositivity following 1 dose, rates of positive neutralising antibody ( $\mathrm{nAb}$ ), cellular responses and adverse events as secondary outcomes. Rates were pooled from single arm studies while rates of seropositivity were compared against the rate in healthy controls for comparator studies using a random effects model and expressed as a pooled odds ratio with $95 \%$ confidence intervals.
\end{abstract}

Forty-four studies (16 mixed group, 28 disease specific) with 7064 patients were included in the analysis ( 2331 following first dose, 4733 following second dose). Overall seropositivity rates were $61-67 \%$ following 2 doses and 37-51\% following 1 dose of COVID-19 vaccine. The lowest seropositivity rate was $51 \%$ in CLL patients and was highest in patients with acute leukaemia (93\%). Following 1 dose, nAb and cellular response rates were $18-63 \%$ and $33-86 \%$ respectively. Active treatment, ongoing or recent treatment with targeted and CD-20 monoclonal antibody therapies within 12 months was associated with poor COVID-19 vaccine immune responses. New approaches to prevention are urgently required to reduce COVID19 infection morbidity and mortality in high-risk patient groups that respond poorly to COVID19 vaccination. 
medRxiv preprint doi: https://doi.org/10.1101/2021.11.06.21265967; this version posted November 8, 2021. The copyright holder for this preprint (which was not certified by peer review) is the author/funder, who has granted medRxiv a license to display the preprint in

All rights reserved. No reuse allowed without permission.

\section{Introduction}

The COVID-19 pandemic caused by the SARS-CoV-2 virus has resulted in global mortality of over 3 million deaths. SARS-CoV-2 is likely to remain an endemic viral pathogen, with new variants continuously emerging ${ }^{1}$. There is a significant burden of morbidity and mortality from COVID-19 infection in haematology patients. Over $80 \%$ of patients require hospitalisation and up to $50 \%$ present with severe disease ${ }^{2-5}$. Approximately $15 \%$ require intensive care unit admission and mortality rates are high at $30-40 \%$ depending on underlying disease ${ }^{2-7}$. Poor control of infection due to immune compromise lead to emergence of new variants which further complicate management ${ }^{8}$.

Vaccination is an effective public health measure to reduce risk of infection and severe complications from COVID-199. However, patients with haematological malignancies were excluded from the pivotal trials which preceeded regulatory approvals of the currently recommended COVID-19 vaccines ${ }^{10-13}$. Understanding the impact of COVID-19 vaccines on cancer patients is critical as social distancing restrictions are being eased in countries with relatively high rates of vaccination coverage ${ }^{14}$. Assessing immune response post-vaccination is the basis of many vaccination studies in patients with haematological malignancy and is often utilised as a surrogate marker of vaccine efficacy ${ }^{15-17}$. These studies are the basis for vaccination recommendations contained within international guidelines ${ }^{18,19}$. Therefore, this study was conducted to systematically review available data on the humoral and cellular immune responses to COVID-19 vaccination in patients with haematological malignancy to build the evidence base for its utility.

\section{Objectives}

The main objective of this systematic review was to assess the immunogenicity (i.e., vaccineinduced immune response) of COVID-19 vaccines in patients with haematological malignancy, stratified by underlying disease type. The secondary objective was to assess the safety of COVID-19 vaccines in the same patient groups.

\section{Methods}

This systematic review was preregistered with PROSPERO (CRD42021276851), and conducted in line with Preferred Reporting Items for Systematic Reviews and Meta-Analyses (PRISMA) guidelines ${ }^{20}$.

\section{Types of studies and participants}

Studies eligible for inclusion into the systematic review were those that investigated the vaccine-induced immunity in patients with haematological malignancy who received at least one dose of COVID-19 vaccine. Randomised controlled trials (RCTs), quasi-RCTs and observational studies were eligible for inclusion. All types of observational studies were included (including prospective and retrospective studies, and studies with or without a control group). This systematic review evaluated all studies that reported on at least one of the following haematology patient groups: 
medRxiv preprint doi: https://doi.org/10.1101/2021.11.06.21265967; this version posted November 8, 2021. The copyright holder for this preprint (which was not certified by peer review) is the author/funder, who has granted medRxiv a license to display the preprint in

All rights reserved. No reuse allowed without permission.

1) All patients with haematological malignancy

2) Patients with multiple myeloma (MM)

3) Patients with chronic lymphocytic leukaemia (CLL)

4) Patients with lymphoma; Hodgkins ( $\mathrm{HL}$ ) and non-Hodgkins lymphoma (NHL)

5) Patients with acute myeloid or lymphocytic leukaemia (AML, ALL)

6) Patients undergoing or who have completed haematopoietic stem cell transplantation (HCT) and chimeric antigen T-cell receptor (CAR-T) therapy

7) Patients with myeloproliferative neoplasm (MPN) and chronic myeloid leukaemia (CML)

\section{Types of intervention and evaluation}

The type of intervention was the use of one or two doses of COVID-19 vaccine (of any type). Immune response to COVID-19 vaccination included humoral and cellular immune responses. For the purpose of this systematic review, humoral response consists of seropositivity which was defined by the SARS-CoV-2 spike/receptor binding domain specific IgG level above the threshold of detection for the assay utilised in each study. Rate of positive neutralising antibody response ( $\mathrm{nAb}$ ) was defined by SARS-CoV-2 specific nAb level above the threshold established by the dedicated neutralisation assay utilised in each study. A positive cellular response was defined by the appropriate increase in frequency of SARS-CoV-2 specific $\mathrm{CD} 4+/ \mathrm{CD} 8+\mathrm{T}$ cells following vaccination according to assays utilised. Where available, the immune response for each malignant patient group was compared to a control group. If there was no comparator group, the immune response for each haematology patient group was described and summarised.

\section{Outcome measures}

The primary outcome was rates of seropositivity following two doses of COVID-19 vaccine stratified by disease groups while secondary outcome measures were the rates of seropositivity following one dose of vaccine, rates of positive nAb response following one and two doses of COVID-19 vaccine, rates of positive cellular response following one and two doses of COVID-19 vaccine and rates of systemic and/or local adverse events (whichever rate was higher) following two doses of COVID-19 vaccine.

\section{Search strategy}

\section{Electronic searching}

Literature searches were conducted by an experienced research librarian (SL) using the following databases to identify relevant articles: Ovid Medline, EMBASE and Cochrane CENTRAL from 1 January 2020 to 31 August 2021 and for articles in English only. A combination of subjects and keyword terms encompassing haematologic cancers, COVID-19 and vaccines and all their associated terms was used for the search. The terms used included: haematological neoplasms, leukemia, lymphoma, multiple myeloma, myeloproliferative 
medRxiv preprint doi: https://doi.org/10.1101/2021.11.06.21265967; this version posted November 8, 2021. The copyright holder for this preprint (which was not certified by peer review) is the author/funder, who has granted medRxiv a license to display the preprint in

All rights reserved. No reuse allowed without permission.

disorders, myelodysplastic-myeloproliferative diseases, stem cell transplantation, bone marrow transplantation, chimeric antigen receptor therapy, COVID-19, SARS-CoV-2, vaccines, vaccination, immunise, immunisation, BNT162b2, CHAdOx1, AZD 1222, mRNA-1273, Ad26, Ad5, NVX-CoV2373. All word variations were searched and Medical subject headings were exploded. The detailed search strategy is summarised in Supplementary Appendix.

\section{Selection of studies}

Studies were excluded from the systematic review if they did not measure or report immunogenicity after COVID-19 vaccination, if insufficient details were reported for the haematology patient groups in mixed group studies, if there were less than 10 patients including case reports, if data was exclusive to paediatric patients less than 18 years of age or animal studies. Studies that were not peer reviewed and/or published such as pre-prints, abstracts and government reports were excluded. Review articles and other publications without original data such as expert opinions, editorials and consensus statements were also excluded.

Study eligibility was assessed by two independent reviewers (BT, JT), and Covidence systematic review software (Veritas Health Innovation, Melbourne, Australia) was used to screen titles, abstracts, and full texts. Irrelevant reports were discarded, and the full texts of the other reports were accessed. Disagreements between the two main reviewers with respect to study eligibility were resolved by discussion, or via consultation with a third author.

\section{Data extraction}

For studies fulfilling inclusion criteria, data were extracted manually and independently by authors (JT, JC, BT) using a predefined data extraction form. Extracted data elements included study design (enrolment, follow up period, randomisation/allocation, laboratory analysis, predefined outcomes, adjusted analysis, funding source), participant information (inclusion criteria, number of participants, characteristics, disease, treatment), intervention (vaccine type, dose, schedule, comparator group) and outcomes (definitions, timing, adverse events).

\section{Assessment of risk of bias}

Two review authors (ZN, MS) independently assessed the risk of bias of each cohort study using the Newcastle-Ottawa Scale ${ }^{21}$. Each included study was assessed based on three domains: (1) the selection of the study groups, (2) the comparability of the study groups, and (3) the ascertainment of outcome of interest. The rating system proposed by Sharmin et $\mathrm{al}^{22}$ was adopted with a good quality study scoring 3 or 4 stars in the selection domain, 1 or 2 stars in comparability domain, and 2 or 3 stars in the outcome domain. For single arm studies, a good quality study would score 3 stars in selection domain, and 2 or 3 stars in outcome domain. 
medRxiv preprint doi: https://doi.org/10.1101/2021.11.06.21265967; this version posted November 8, 2021. The copyright holder for this preprint (which was not certified by peer review) is the author/funder, who has granted medRxiv a license to display the preprint in

All rights reserved. No reuse allowed without permission.

\section{Measures of treatment effect}

For each study, the number of patients achieving seropositivity and the total number of patients receiving vaccination was extracted and expressed as a proportion. For the metaanalysis, rate of response following Ad26 vaccine was analysed at the same time point and therefore summarised as part of a two-vaccine dose response. For each haematology disease group, the proportions from each study were pooled and expressed as an overall proportion (response rate) with $95 \%$ confidence intervals $(95 \% \mathrm{Cl})$ utilising inverse variance/generalised mixed modelling.

For each study with a control group, the number of patients with seropositivity in each group and the total number of patients receiving vaccination were extracted, expressed as a proportion with $95 \% \mathrm{Cl}$ and compared against each other. A meta-analysis was performed if there were two or more studies identified with a similar population and sufficient data for the outcomes of interest. The rate of seropositivity as a dichotomous outcome of interest across studies was summarised using a random effects model and expressed as a pooled odds ratio with $95 \% \mathrm{Cl}$. Analysis was performed using metaprop function on R 4.1.1 (R foundation for Statistical Computing, Vienna).

\section{Assessment of heterogeneity}

Clinical and methodological heterogeneity between included studies was assessed by comparing the key patient factors and study factors (vaccine type, type of assay utilised, threshold for positive response, duration of follow up). Statistical heterogeneity was assessed by using the $\mathrm{I}^{2}$ statistic and $\mathrm{Chi}^{2}$ with a $p$ value $\leq 0.05$ considered significant for the presence of heterogeneity.

\section{Management of missing data}

If available, reason(s) for missing data were outlined. Due to time limitations, further information was not sought from the original author/corresponding author(s).

\section{Subgroup analysis}

Pre-planned subgroup analysis was performed to evaluate impact of active treatment (versus no active treatment), anti-CD-20 therapy in the last 12 months including current CD-20 therapy (versus anti-CD-20 therapy 12 or more months ago), targeted therapy (defined as Bruton's tyrosine kinase inhibitor [BTKi], BCL-2 antagonist venetoclax) in last 12 months (versus no targeted therapy), timing of vaccination in relation to HCT (within 12 months versus longer than 12 months) and response by types of vaccine (BNT162b2 vs others including mRNA-1273 [Spikevax, Moderna], ChAdOx1 [Vaxzevria, AstraZeneca] or Ad26 [Janssen]). For subgroup analysis only studies containing sufficient level of detail for the outcome of interest (e.g. therapy $<12$ months) were included. For analysis by vaccine type, only studies reporting use and immune response of multiple vaccines types were included.

\section{Results}

Search results

A search of electronic databases yielded 520 results and following exclusion of duplicate results, 411 abstracts were reviewed. Forty-eight studies were identified for full text review 
medRxiv preprint doi: https://doi.org/10.1101/2021.11.06.21265967; this version posted November 8, 2021. The copyright holder for this preprint (which was not certified by peer review) is the author/funder, who has granted medRxiv a license to display the preprint in

All rights reserved. No reuse allowed without permission.

and subsequently 44 studies fulfilled inclusion criteria and underwent data extraction (Figure 1). Overall there were 44 studies of COVID-19 vaccination in patients with haematological malignancy. Sixteen studies ${ }^{23-38}$ involved mixed group of patients with various underlying haematological malignancies and 28 studies focused on specific malignancies and treatments; 8 myeloma studies $^{39-46}, 6 \mathrm{CLL}^{\text {studies }}{ }^{47-52}$, 4 lymphoma studies ${ }^{53-56}, 4$ studies of HCT $^{57,58}$ and CAR-T ${ }^{59,60}$ and 6 MPN studies ${ }^{61-66}$. A total of 7064 patients were included in the analysis (2331 following first dose and 4733 following second dose). Characteristics of patients, primary and secondary outcomes in included studies are summarised in Table 1.

\section{Risk of bias and quality assessment}

Overall 23 studies (52\%) were evaluated to be good or fair quality (Good $=11$, Fair $=12$ ) with low risk of bias whilst the remaining 21 studies were rated as poor quality (high risk of bias) predominantly due to lack of details regarding patient selection, demonstration that outcome of interest was not present at start of study, comparability of cohorts (design or analysis) and follow up duration. Risk of bias and quality assessment of studies are summarised in Supplementary Table 1.

\section{Seropositivity rates}

There were 44 studies measuring humoral immune responses in patients with haematological malignancy. The majority of studies evaluated the use of BNT162b2 (Tozinameran, Pfizer) and utilised SARS-CoV-2 spike specific IgG levels above the threshold of detection (seropositivity). Several studies attempted to establish potential thresholds for clinical protection with higher antibody levels than the seropositivity threshold utilised. Malard et. al. correlated SARS-CoV2 spike IgG levels with $\mathrm{nAb}$ levels and $\geq 3100 \mathrm{AU} / \mathrm{mL}$ on the Abbott assay was predictive of a $n A b \geq 30 \%{ }^{33}$. Utilising this threshold, the rate of humoral response was $47 \%$ in haematology patients compared to $97 \%$ of healthy controls following second dose of the BNT162b2 vaccine $^{33}$. Pimpinelli et. al. also evaluated humoral responses utilising a higher threshold of $\geq$ $80 \mathrm{AU} / \mathrm{ml}$ (Diasorin, Italy) and noted response rates of $55 \%$ for myeloma patients and $84 \%$ for MPN patients compared to $97 \%$ for healthy controls ${ }^{36}$. Other studies correlated SARS-CoV-2 IgG levels with plaque reduction neutralisation tests or with levels seen in clinical vaccination trials. Stampfer et. al. defined $>250 \mathrm{IU} / \mathrm{ml}$ as a clinically relevant response which was attained by $45 \%$ of myeloma patients after two doses of a COVID-19 vaccine ${ }^{43}$. For HCT patients, Redjoul et. al. utilised a threshold of $4160 \mathrm{AU} / \mathrm{ml}$ and $59 \%$ of patients achieved this response after two doses ${ }^{58}$.

Overall pooled seropositivity rates in haematological malignancy were $61 \%$ and $67 \%$ in single arm and comparator studies respectively, following two doses of COVID-19 vaccination. Following a single dose, the pooled seropositivity rates were $51 \%$ and $37 \%$ in single arm and comparator studies respectively. Compared to healthy or aged matched controls, patients with haematological malignancy were less likely to achieve seropositivity with odds ratio (OR) of 0.05 (95\% confidence interval [95\% Cl] 0.02-0.15, $p<0.01)$ following two doses and OR of $0.10(95 \% \mathrm{Cl} 0.04-0.29, p<0.01)$ following a single dose of COVID-19 vaccine. Heterogeneity was 86 and $88 \%$ respectively $(p<0.01)$. Pooled seropositivity rates by disease type and vaccine doses are summarised in Table 2 . Overall results were graded moderate quality due to statistical and clinical heterogeneity and the proportion of high risk of bias studies (48\%). 
medRxiv preprint doi: https://doi.org/10.1101/2021.11.06.21265967; this version posted November 8, 2021. The copyright holder for this preprint (which was not certified by peer review) is the author/funder, who has granted medRxiv a license to display the preprint in

All rights reserved. No reuse allowed without permission.

Patients with myeloma

There were 8 dedicated studies and 9 other studies that reported immune response rates in myeloma patients (Supplementary Table 2). For the two studies by Terpos et. al, only nAb at two levels were reported and thresholds of $\geq 30 \%$ and $\geq 50 \%$ were utilised to define seropositivity and rate of positive $n A b$ respectively ${ }^{44,45}$. There were 1218 myeloma patients who received 2 doses of vaccine and seropositivity rates were $76-80 \%$. Seropositivity rates were $29-43 \%$ following 1 dose of COVID-19 vaccine in 685 patients. The OR for achieving seropositivity was $0.09(95 \% \mathrm{Cl} 0.03-0.29, p<0.01)$ in myeloma patients compared to healthy control group following 2 doses and $0.23(95 \% \mathrm{Cl} 0.05-0.99, p=0.05)$ following 1 vaccine dose (Table 2).

Patients with CLL

A total of 1557 CLL patients in 12 studies ( 6 CLL specific, 6 haematology) were included in this review (Supplementary Table 3). Pooled seropositivity rates were $51 \%$ in 1446 CLL patients following 2 doses of COVID-19 vaccine. Rate of seropositivity was 18\% following 1 dose of COVID-19 vaccine and it was $37 \%$ in one single arm study by Ollila et. al ${ }^{35}$. ORs for seropositivity were $0.01(95 \% \mathrm{Cl} 0.01-0.03, p<0.01)$ and $0.03(95 \% \mathrm{Cl} 0.00-0.80, p=0.05)$ for CLL patients following 2 doses and 1 dose of vaccine compared to healthy controls.

Patients with lymphoma

For 1296 patients with lymphoma across 11 studies included (Supplementary Table 4), pooled seropositivity rates were 52-55\% following 2 doses and 33\% following 1 dose of COVID-19 vaccine. Compared to healthy cohort, ORs for achieving seropositivity were 0.01 to 0.02 for lymphoma patients (Table 2).

Patients following HCT and CAR-T

A total of 6 studies included in this review reported on immune responses following HCT and CAR-T therapy (Supplementary Table 5). Two studies involved allogeneic HCT (alloHCT) patients ${ }^{57,58}$, one included alloHCT and CAR-T treated patients ${ }^{59}$ and the other study included all HCT and CAR-T patients ${ }^{60}$. Two studies were larger studies of haematology patients with subset of HCT and CAR-T patients ${ }^{28,29} .422$ patients were included consisting of 401 patients who had 2 doses and the remainder received 1 dose of COVID-19 vaccine. Pooled seropositivity rate was $61 \%$ following 2 COVID-19 vaccine doses. For patients following alloHCT the rate was $74 \%$ while following CAR-T, it was $31 \%$. In a single study with a healthy control cohort, seropositivity rate was $81 \%$ in autologous HCT patients compared to $99 \%{ }^{29}$. In the only study of immune response following one COVID-19 vaccine dose, rate of seropositivity was $38 \%$ in alloHCT patients ${ }^{57}$.

Patients with acute leukaemia and MDS

There were no dedicated studies of COVID-19 vaccination in patients with acute leukaemia. A subset of 126 patients with acute leukaemia and MDS were reported in 6 studies (Supplementary Table 6) and seropositivity rate was 93\% following 2 doses of COVID-19 vaccine. In a single study, the seropositivity rate was $80 \%$ in acute leukaemia, $94 \%$ in MDS patients compared to $99 \%$ in the control group ${ }^{29}$. No patients with acute leukaemia mounted an immune response following a single vaccine dose compared to $86 \%$ of controls ${ }^{34}$. 
medRxiv preprint doi: https://doi.org/10.1101/2021.11.06.21265967; this version posted November 8, 2021. The copyright holder for this preprint (which was not certified by peer review) is the author/funder, who has granted medRxiv a license to display the preprint in

All rights reserved. No reuse allowed without permission.

Patients with MPN and CML

Of 12 studies encompassing 503 MPN and CML patients (281 following 2 doses, 222 following a single dose), rates of seropositivity were $87-88 \%$ following 2 doses and $54-71 \%$ following 1 dose of vaccine. Compared to a healthy patient cohort, the OR was 0.07 ( $95 \% \mathrm{Cl} 0.0-1.55$, $p=0.06$ ) of MPN/CML patient achieving seropositivity with 2 doses of COVID-19 vaccine and $0.13(95 \% \mathrm{Cl} 0.01-1.71, p=0.09)$ after a single dose.

Rates of neutralising antibody, cellular response and adverse events

Only 6 studies (14\%) reported $\mathrm{nAb}$ responses and 4 studies (9\%) reported cellular responses. In the only study on nAb following 2 COVID-19 vaccine doses, $71 \%$ of myeloma patients achieved a positive nAb response compared to $90 \%$ of the control group ${ }^{45}$. Following 1 dose of COVID-19 vaccine, the overall pooled rate of a positive nAb response was $18 \%$ for all patients with haematological malignancy (Table 3). The pooled rate of 2 single arm studies of MPN patients was $63 \%$. For cellular responses following COVID-19 vaccination, the rate of achieving a positive response was $40-75 \%$ for all patients following 2 doses and 33-86\% following a single dose. In a single study of alloHCT and CAR-T patients, cellular response rates were $19 \%$ and $50 \%$ respectively following 2 doses $^{59}$. In MPN patients, this rate was $86 \%$ following one dose ${ }^{64,65}$. In 10 studies (22\%) the rate of at least one systemic or local adverse event was reported. Overall, the pooled rate of at least one adverse event was $36 \%$ following 2 doses and $39 \%$ following a single dose (Table 3 ).

\section{Subgroup analysis}

Study characteristics and outcomes of studies included in subgroup analyses are summarised in Supplementary Tables 8-12. Vaccination with 2 vaccine doses during active therapy was associated with seropositivity rates of $28 \%$ compared to $62 \%$ off therapy with OR 0.21 (95\% $\mathrm{Cl} 0.06-0.67, p=0.02)$. Lower seropositivity rates (19\% vs. $61 \%)$ were reported with vaccination during or within 12 months of CD-20 antibody therapy compared to vaccination 12 or more months after completion of therapy. Use of targeted therapy was associated with a pooled seropositivity rate of $35 \%$ following 2 doses of COVID-19 vaccine. Seropositivity rates did not differ by timing of vaccination in relation to HCT (66\% vs $68 \%$ ) or vaccine type $(62 \%$ vs $68 \%$, $95 \%$ vs 91\%) following 1 or 2 doses. Table 4 summarises the seropositivity rates by each subgroup analysed.

\section{Sensitivity analysis}

Exclusion of studies that were assessed as poor quality and high risk of bias did not alter the pooled seropositivity rates (single arm) but in comparator studies, OR was now $0.31(95 \% \mathrm{Cl}$ $0.13-0.78, p=0.03$ ) following 1 dose instead of 0.10 (Supplementary Table 13).

\section{Discussion}

In this systematic review and meta-analysis of over 7000 patients with haematological malignancy, rate of seropositivity was 61-67\% following 2 doses and 37-51\% following 1 dose of COVID-19 vaccination. Compared to age matched and non-matched healthy controls primarily healthcare workers, odds of achieving seropositivity were significantly lower by $95 \%$ and $90 \%$ following 2 doses and 1 dose of COVID-19 vaccination respectively. Statistical heterogeneity was substantial at over $80 \%$ and studies were also clinically heterogenous due 
medRxiv preprint doi: https://doi.org/10.1101/2021.11.06.21265967; this version posted November 8, 2021. The copyright holder for this preprint (which was not certified by peer review) is the author/funder, who has granted medRxiv a license to display the preprint in

All rights reserved. No reuse allowed without permission.

to the variety of underlying haematological malignancies, lack of standardised laboratory platforms by which to measure immune response to vaccination and variable follow up periods. Reassuringly, reported rates of at least one adverse effect following vaccination were lower at $36 \%$ compared to rates reported in clinical trials of the general population ${ }^{10,13}$.

Amongst different haematological malignancies, pooled seropositivity rates following 2 doses were highest at close to $90 \%$ in patients with acute leukaemia, MDS and MPN and the lowest at $51 \%$ in CLL patients. Patients with CLL respond poorly to vaccination, especially to new or novel antigens compared to recall antigens from previous infections or vaccination ${ }^{67}$. Poor response is compounded by use of B-cell depleting and targeted therapies such as CD-20 monoclonal antibodies and $\mathrm{BTK}^{67}$. Immune response to other vaccines including seasonal influenza vaccine is negatively impacted by these therapies and the poor response persists for at least 6 to 12 months following cessation of therapy ${ }^{68}$.

A similar negative impact of treatment on COVID-19 vaccine responses was noted in subgroup analysis of published studies. Rates of seropositivity were lower in the setting of active treatment (28\%) and the lowest response rates of $19 \%, 35 \%$ and $31 \%$ were reported in the setting of current or CD-20 monoclonal antibody therapy within 12 months, targeted therapies and following CAR-T cell therapy. Seropositivity rates were two to three times higher at 61 and $62 \% \%$ when patients were vaccinated when not on active therapy or 12 or more months following completion of CD-20 monoclonal antibody respectively.

Unvaccinated CLL patients have a high burden of morbidity from COVID-19 infection with close to $90 \%$ of patients requiring hospital admission, 35\% intensive care unit admission and mortality rates ${ }^{4}$. Yet, CLL patients have poor humoral responses to vaccination at $18 \%$ following 1 dose and 51\% following 2 doses. In CLL patients, immune suppression from underlying disease and ongoing treatments such as anti-CD20 monoclonal antibodies and BTKi continue to pose a risk for SARS-CoV-2 infection and concurrently limit protective responses from vaccination. Although vaccination remains highly recommended, new strategies are required to further improve immune responses in this high-risk patient population. In other immune compromised groups, the use of an additional dose of COVID19 vaccine improved serological response rates by $37 \%$ and use of heterologous vaccination schedules (mixing vaccine types) appear promising ${ }^{69-71}$. International health bodies now recommend third COVID-19 vaccine doses in immune compromised patients including haematological malignancy ${ }^{72,73}$. Heterologous prime-boost or use of high dose vaccine formulations have been utilised in randomised trials of seasonal influenza vaccination in haematology and HCT patient with mixed success ${ }^{17,74}$. In addition, other preventative approaches such as the use of anti-SARS-CoV-2 monoclonal antibody therapy as pre exposure (NCT04625725) and post exposure prophylaxis require further evaluation in vulnerable patient groups who respond poorly to vaccination ${ }^{75}$.

Serological responses are classically utilised as surrogate end points for clinical efficacy in clinical trials of vaccination in patients with haematological malignancy ${ }^{15-17}$. Serological thresholds for protection (seroprotection) following vaccination have been established for infections such as seasonal influenza ${ }^{17}$. In the majority of studies included in this review, however, the outcome of interest was seropositivity as defined by antibody levels above the detection threshold. This is not equivalent to seroprotection as thresholds have not been 
medRxiv preprint doi: https://doi.org/10.1101/2021.11.06.21265967; this version posted November 8, 2021. The copyright holder for this preprint (which was not certified by peer review) is the author/funder, who has granted medRxiv a license to display the preprint in

All rights reserved. No reuse allowed without permission.

standardised nor established across the variety of commercial and research platforms utilised by these studies. Some authors such as Redjoul, Stampfer and Malard et. al. have attempted to define serological thresholds that correlate with $\mathrm{nAb}$ and clinical protection $33,43,58$. Unsurprisingly a lower proportion of patients (by 20-35\% compared to pooled rates) achieve these higher antibody thresholds $33,43,58$. For serological response measurement to guide clinical management of COVID-19 vaccination, further work is required to achieve harmonisation across testing platforms and to derive and validate thresholds that correlate with clinical protection.

Measurement of serological responses only offers a glimpse of the potential breadth of immune responses to COVID-19 vaccination. Both $\mathrm{nAb}$ and cellular responses to vaccination play complementary and vital roles in protection against COVID-19 and remain under reported ${ }^{76-78}$. As reported in $14 \%$ of studies, at least $18 \%$ of haematology patients achieved a positive $\mathrm{nAb}$ response. Positive cellular response rates were at least $15 \%$ higher than $\mathrm{nAb}$ responses following 1 or 2 vaccine doses. While serological responses have been utilised as surrogate endpoints in vaccination studies of immune compromised patients, more larger studies are required to identify new immune markers for vaccine response and to determine efficacy of vaccination.

There are several limitations to this review. In particular the moderate quality of findings due to significant clinical and statistical heterogeneity of included studies and the proportion of poorer quality studies. In line with other established studies of vaccination in haematology patients, only immune response data was analysed as clinical efficacy data was limited.

In conclusion, this systematic review and meta-analysis has comprehensively summarised the latest data on response to COVID-19 vaccination in patients with haematological malignancy. Overall, seropositive rates were reasonable at $67 \%$ following two doses of vaccination respectively. Higher risk patient groups were identified, namely patients with CLL and patients receiving active therapy including targeted and CD-20 monoclonal therapies. New approaches to high risk patients who are poor responders to vaccination are urgently required.

\section{Acknowledgement}

B.W.T is supported by the Australian Government Medical Research Future Fund Investigator Fellowship. M.A.S is supported by the National Health and Medical Research Council Investigator fellowship.

\section{Authorship contributions}

B.W.T coordinated the study, performed abstract and full text screening, data extraction and manuscript writing. J.T performed abstract and full text screening and data extraction. J.C. developed the study protocol and performed data extraction. S.L. developed the search strategy. T.S. conducted the statistical analysis. Z.N and M.A.S conducted the risk of bias assessment. All authors reviewed and revised the manuscript.

\section{Conflict of interest}

M.A.S. has received research funding and honoraria from Pfizer, Merck Sharp and Dohme and research funding from Gilead. B.W.T has received research funding and honoraria from CSLBehring, Merck Sharp and Dohme and Sanofi. 
medRxiv preprint doi: https://doi.org/10.1101/2021.11.06.21265967; this version posted November 8, 2021. The copyright holder for this preprint (which was not certified by peer review) is the author/funder, who has granted medRxiv a license to display the preprint in

All rights reserved. No reuse allowed without permission.

\section{References}

1. Phillips N. The coronavirus is here to stay - here's what that means. Nature. 2021;590(7846):382-384.

2. Wood WA, Neuberg DS, Thompson JC, et al. Outcomes of patients with hematologic malignancies and COVID-19: a report from the ASH Research Collaborative Data Hub. Blood Adv. 2020;4(23):5966-5975.

3. Sharma A, Bhatt NS, St Martin A, et al. Clinical characteristics and outcomes of COVID19 in haematopoietic stem-cell transplantation recipients: an observational cohort study. Lancet Haematol. 2021;8(3):e185-e193.

4. Mato AR, Roeker LE, Lamanna N, et al. Outcomes of COVID-19 in patients with CLL: a multicenter international experience. Blood. 2020;136(10):1134-1143.

5. Regalado-Artamendi I, Jimenez-Ubieto A, Hernandez-Rivas JA, et al. Risk Factors and Mortality of COVID-19 in Patients With Lymphoma: A Multicenter Study. Hemasphere. 2021;5(3):e538.

6. Chari A, Samur MK, Martinez-Lopez J, et al. Clinical features associated with COVID-19 outcome in multiple myeloma: first results from the International Myeloma Society data set. Blood. 2020;136(26):3033-3040.

7. Cook G, John Ashcroft A, Pratt G, et al. Real-world assessment of the clinical impact of symptomatic infection with severe acute respiratory syndrome coronavirus (COVID-19 disease) in patients with multiple myeloma receiving systemic anti-cancer therapy. $\mathrm{Br} J$ Haematol. 2020;190(2):e83-e86.

8. Corey L, Beyrer C, Cohen MS, Michael NL, Bedford T, Rolland M. SARS-CoV-2 Variants in Patients with Immunosuppression. N Engl J Med. 2021;385(6):562-566.

9. Vasileiou E, Simpson CR, Shi T, et al. Interim findings from first-dose mass COVID-19 vaccination roll-out and COVID-19 hospital admissions in Scotland: a national prospective cohort study. Lancet. 2021;397(10285):1646-1657.

10. Polack FP, Thomas SJ, Kitchin N, et al. Safety and Efficacy of the BNT162b2 mRNA Covid-19 Vaccine. N Engl J Med. 2020;383(27):2603-2615.

11. Heath PT, Galiza EP, Baxter DN, et al. Safety and Efficacy of NVX-CoV2373 Covid-19 Vaccine. N EnglJ Med. 2021.

12. Voysey M, Clemens SAC, Madhi SA, et al. Safety and efficacy of the ChAdOx1 nCoV-19 vaccine (AZD1222) against SARS-CoV-2: an interim analysis of four randomised controlled trials in Brazil, South Africa, and the UK. Lancet. 2021;397(10269):99-111.

13. Baden LR, El Sahly HM, Essink B, et al. Efficacy and Safety of the mRNA-1273 SARSCoV-2 Vaccine. N Engl J Med. 2021;384(5):403-416.

14. Tau N, Manuel O, Rozen-Zvi B, Shargian L, Yahav D. Precautions after vaccinating immunosuppressed patients with mRNA-based vaccines against SARS-CoV-2: does one size fit all? Clin Microbiol Infect. 2021.

15. Cordonnier C, Labopin M, Chesnel V, et al. Randomized study of early versus late immunization with pneumococcal conjugate vaccine after allogeneic stem cell transplantation. Clin Infect Dis. 2009;48(10):1392-1401.

16. Cordonnier $C$, Ljungman $P$, Juergens $C$, et al. Immunogenicity, safety, and tolerability of 13-valent pneumococcal conjugate vaccine followed by 23-valent pneumococcal polysaccharide vaccine in recipients of allogeneic hematopoietic stem cell transplant aged >/=2 years: an open-label study. Clin Infect Dis. 2015;61(3):313-323. 
medRxiv preprint doi: https://doi.org/10.1101/2021.11.06.21265967; this version posted November 8, 2021. The copyright holder for this preprint (which was not certified by peer review) is the author/funder, who has granted medRxiv a license to display the preprint in

All rights reserved. No reuse allowed without permission.

17. Teh BW, Leung VKY, Mordant FL, et al. A randomised trial of two 2-dose influenza vaccination strategies for patients following autologous haematopoietic stem cell transplantation. Clin Infect Dis. 2020.

18. Tomblyn $M$, Chiller $T$, Einsele $H$, et al. Guidelines for preventing infectious complications among hematopoietic cell transplantation recipients: a global perspective. Biol Blood Marrow Transplant. 2009;15(10):1143-1238.

19. Rubin LG, Levin MJ, Ljungman P, et al. 2013 IDSA clinical practice guideline for vaccination of the immunocompromised host. Clin Infect Dis. 2014;58(3):e44-100.

20. Page MJ, McKenzie JE, Bossuyt PM, et al. The PRISMA 2020 statement: an updated guideline for reporting systematic reviews. BMJ. 2021;372:n71.

21. Wells G SB, O'Connell D, Peterson J, Welch V, Losos M, Tugwell P. The NewcastleOttawa Scale (NOS) for assessing the quality of nonrandomised studies in meta-analyses. 2013.

22. Sharmin S, Kypri K, Khanam M, Wadolowski M, Bruno R, Mattick RP. Parental Supply of Alcohol in Childhood and Risky Drinking in Adolescence: Systematic Review and MetaAnalysis. Int J Environ Res Public Health. 2017;14(3).

23. Addeo A, Shah PK, Bordry N, et al. Immunogenicity of SARS-CoV-2 messenger RNA vaccines in patients with cancer. Cancer Cell. 2021;39(8):1091-1098 e1092.

24. Agha ME, Blake M, Chilleo C, Wells A, Haidar G. Suboptimal Response to Coronavirus Disease 2019 Messenger RNA Vaccines in Patients With Hematologic Malignancies: A Need for Vigilance in the Postmasking Era. Open Forum Infect Dis. 2021;8(7):ofab353.

25. Benda M, Mutschlechner B, Ulmer H, et al. Serological SARS-CoV-2 antibody response, potential predictive markers and safety of BNT162b2 mRNA COVID-19 vaccine in haematological and oncological patients. Br J Haematol. 2021.

26. Cohen D, Hazut Krauthammer S, Cohen YC, et al. Correlation between BNT162b2 mRNA Covid-19 vaccine-associated hypermetabolic lymphadenopathy and humoral immunity in patients with hematologic malignancy. Eur J Nucl Med Mol Imaging. 2021.

27. Gavriatopoulou M, Terpos E, Kastritis E, et al. Low neutralizing antibody responses in WM, CLL and NHL patients after the first dose of the BNT162b2 and AZD1222 vaccine. Clin Exp Med. 2021.

28. Greenberger LM, Saltzman LA, Senefeld JW, Johnson PW, DeGennaro L, Nichols GL. Antibody response to SARS-CoV-2 vaccines in patients with hematologic malignancies. Cancer Cell. 2021;39(8):1031-1033.

29. Herzog Tzarfati K, Gutwein O, Apel A, et al. BNT162b2 COVID-19 vaccine is significantly less effective in patients with hematologic malignancies. Am J Hematol. 2021.

30. Iacono D, Cerbone L, Palombi L, et al. Serological response to COVID-19 vaccination in patients with cancer older than 80 years. J Geriatr Oncol. 2021.

31. Jurgens EM, Ketas TJ, Zhao Z, et al. Serologic response to mRNA COVID-19 vaccination in lymphoma patients. Am J Hematol. 2021.

32. Maneikis K, Sablauskas K, Ringeleviciute $U$, et al. Immunogenicity of the BNT162b2 COVID-19 mRNA vaccine and early clinical outcomes in patients with haematological malignancies in Lithuania: a national prospective cohort study. Lancet Haematol. 2021.

33. Malard F, Gaugler B, Gozlan J, et al. Weak immunogenicity of SARS-CoV-2 vaccine in patients with hematologic malignancies. Blood Cancer J. 2021;11(8):142.

34. Monin L, Laing AG, Munoz-Ruiz M, et al. Safety and immunogenicity of one versus two doses of the COVID-19 vaccine BNT162b2 for patients with cancer: interim analysis of a prospective observational study. Lancet Oncol. 2021;22(6):765-778. 
medRxiv preprint doi: https://doi.org/10.1101/2021.11.06.21265967; this version posted November 8, 2021. The copyright holder for this preprint (which was not certified by peer review) is the author/funder, who has granted medRxiv a license to display the preprint in

All rights reserved. No reuse allowed without permission.

35. Ollila TA, Lu S, Masel R, et al. Antibody Response to COVID-19 Vaccination in Adults With Hematologic Malignant Disease. JAMA Oncol. 2021.

36. Pimpinelli F, Marchesi F, Piaggio G, et al. Fifth-week immunogenicity and safety of antiSARS-CoV-2 BNT162b2 vaccine in patients with multiple myeloma and myeloproliferative malignancies on active treatment: preliminary data from a single institution. J Hematol Oncol. 2021;14(1):81.

37. Re D, Barriere J, Chamorey E, et al. Low rate of seroconversion after mRNA anti-SARSCoV-2 vaccination in patients with hematological malignancies. Leuk Lymphoma. 2021:1-3.

38. Thakkar A, Gonzalez-Lugo JD, Goradia N, et al. Seroconversion rates following COVID19 vaccination among patients with cancer. Cancer Cell. 2021.

39. Avivi I, Balaban R, Shragai T, et al. Humoral response rate and predictors of response to BNT162b2 mRNA COVID19 vaccine in patients with multiple myeloma. Br J Haematol. 2021. 40. Bird S, Panopoulou A, Shea RL, et al. Response to first vaccination against SARS-CoV-2 in patients with multiple myeloma. Lancet Haematol. 2021;8(6):e389-e392.

41. Ghandili S, Schonlein M, Lutgehetmann M, et al. Post-Vaccination Anti-SARS-CoV-2Antibody Response in Patients with Multiple Myeloma Correlates with Low CD19+ BLymphocyte Count and Anti-CD38 Treatment. Cancers (Basel). 2021;13(15).

42. Ramasamy K, Sadler R, Jeans $S$, et al. COVID symptoms, testing, shielding impact on patient-reported outcomes and early vaccine responses in individuals with multiple myeloma. Br J Haematol. 2021.

43. Stampfer SD, Goldwater MS, Jew S, et al. Response to mRNA vaccination for COVID19 among patients with multiple myeloma. Leukemia. 2021.

44. Terpos E, Trougakos IP, Gavriatopoulou M, et al. Low neutralizing antibody responses against SARS-CoV-2 in older patients with myeloma after the first BNT162b2 vaccine dose. Blood. 2021;137(26):3674-3676.

45. Terpos E, Gavriatopoulou M, Ntanasis-Stathopoulos I, et al. The neutralizing antibody response post COVID-19 vaccination in patients with myeloma is highly dependent on the type of anti-myeloma treatment. Blood Cancer J. 2021;11(8):138.

46. Van Oekelen O, Gleason CR, Agte $S$, et al. Highly variable SARS-CoV-2 spike antibody responses to two doses of COVID-19 RNA vaccination in patients with multiple myeloma. Cancer Cell. 2021.

47. Benjamini O, Rokach L, Itchaki G, et al. Safety and efficacy of BNT162b mRNA Covid19 Vaccine in patients with chronic lymphocytic leukemia. Haematologica. 2021.

48. Del Poeta G, Bomben R, Polesel J, et al. COVID-19 vaccination: Evaluation of risk for protection failure in chronic lymphocytic leukemia patients. Hematol Oncol. 2021.

49. Herishanu Y, Avivi I, Aharon A, et al. Efficacy of the BNT162b2 mRNA COVID-19 vaccine in patients with chronic lymphocytic leukemia. Blood. 2021;137(23):3165-3173.

50. Parry H, Mcllroy G, Bruton R, et al. Antibody responses after first and second Covid-19 vaccination in patients with chronic lymphocytic leukaemia. Blood Cancer J. 2021;11(7):136.

51. Roeker LE, Knorr DA, Thompson MC, et al. COVID-19 vaccine efficacy in patients with chronic lymphocytic leukemia. Leukemia. 2021.

52. Tadmor T, Benjamini O, Braester A, Rahav G, Rokach L. Antibody persistence 100 days following the second dose of BNT162b mRNA Covid19 vaccine in patients with chronic lymphocytic leukemia. Leukemia. 2021.

53. Ghione P, Gu JJ, Attwood K, et al. Impaired humoral responses to COVID-19 vaccination in patients with lymphoma receiving B-cell directed therapies. Blood. 2021. 
medRxiv preprint doi: https://doi.org/10.1101/2021.11.06.21265967; this version posted November 8, 2021. The copyright holder for this preprint (which was not certified by peer review) is the author/funder, who has granted medRxiv a license to display the preprint in

All rights reserved. No reuse allowed without permission.

54. Gurion R, Rozovski U, Itchaki G, et al. Humoral serologic response to the BNT162b2 vaccine is abrogated in lymphoma patients within the first 12 months following treatment with anti-CD2O antibodies. Haematologica. 2021.

55. Lim SH, Campbell N, Johnson $\mathrm{M}$, et al. Antibody responses after SARS-CoV-2 vaccination in patients with lymphoma. Lancet Haematol. 2021;8(8):e542-e544.

56. Perry C, Luttwak E, Balaban R, et al. Efficacy of the BNT162b2 mRNA COVID-19 vaccine in patients with B-cell non-Hodgkin lymphoma. Blood Adv. 2021;5(16):3053-3061.

57. Easdale S, Shea R, Ellis L, et al. Serologic Responses following a Single Dose of SARSCov-2 Vaccination in Allogeneic Stem Cell Transplantation Recipients. Transplant Cell Ther. 2021.

58. Redjoul R, Le Bouter A, Beckerich F, Fourati S, Maury S. Antibody response after second BNT162b2 dose in allogeneic HSCT recipients. Lancet. 2021;398(10297):298-299.

59. Ram R, Hagin D, Kikozashvilli N, et al. Safety and Immunogenicity of the BNT162b2 mRNA COVID-19 Vaccine in Patients after Allogeneic HCT or CD19-based CART therapy-A Single-Center Prospective Cohort Study. Transplant Cell Ther. 2021.

60. Dhakal B, Abedin SM, Fenske TS, et al. Response to SARS-CoV-2 vaccination in patients after hematopoietic cell transplantation and CAR-T cell therapy. Blood. 2021.

61. Caocci G, Mulas O, Mantovani D, et al. Ruxolitinib does not impair humoral immune response to COVID-19 vaccination with BNT162b2 mRNA COVID-19 vaccine in patients with myelofibrosis. Ann Hematol. 2021.

62. Chowdhury O, Bruguier H, Mallett G, et al. Impaired antibody response to COVID-19 vaccination in patients with chronic myeloid neoplasms. Br J Haematol. 2021.

63. Guglielmelli P, Mazzoni A, Maggi L, et al. Impaired response to first SARS-CoV-2 dose vaccination in myeloproliferative neoplasm patients receiving ruxolitinib. Am J Hematol. 2021.

64. Harrington P, Doores KJ, Radia D, et al. Single dose of BNT162b2 mRNA vaccine against severe acute respiratory syndrome coronavirus-2 (SARS-CoV-2) induces neutralising antibody and polyfunctional T-cell responses in patients with chronic myeloid leukaemia. $\mathrm{Br} J$ Haematol. 2021.

65. Harrington $\mathrm{P}$, de Lavallade $\mathrm{H}$, Doores KJ, et al. Single dose of BNT162 b2 mRNA vaccine against SARS-CoV-2 induces high frequency of neutralising antibody and polyfunctional T-cell responses in patients with myeloproliferative neoplasms. Leukemia. 2021.

66. Pimpinelli F, Marchesi F, Piaggio $G$, et al. Lower response to BNT162b2 vaccine in patients with myelofibrosis compared to polycythemia vera and essential thrombocythemia. J Hematol Oncol. 2021;14(1):119.

67. Pleyer C, Ali MA, Cohen JI, et al. Effect of Bruton tyrosine kinase inhibitor on efficacy of adjuvanted recombinant hepatitis B and zoster vaccines. Blood. 2021;137(2):185-189.

68. Vijenthira A, Gong I, Betschel SD, Cheung M, Hicks LK. Vaccine response following antiCD20 therapy: a systematic review and meta-analysis of 905 patients. Blood Adv. 2021;5(12):2624-2643.

69. Hall V.G. FV, Ku T, lerullo M, Majchrzak-Kita B, Chaparro C., Selzner N., Schiff J, McDonald M., Tomlinson G., Kulasingam V., Kumar D., Humar A. Randomized Trial of a Third Dose of mRNA-1273 Vaccine in Transplant Recipients. New England Journal of Medicine. 2021.

70. Liu X, Shaw RH, Stuart ASV, et al. Safety and immunogenicity of heterologous versus homologous prime-boost schedules with an adenoviral vectored and mRNA COVID-19 vaccine (Com-COV): a single-blind, randomised, non-inferiority trial. Lancet. 2021. 
medRxiv preprint doi: https://doi.org/10.1101/2021.11.06.21265967; this version posted November 8, 2021. The copyright holder for this preprint (which was not certified by peer review) is the author/funder, who has granted medRxiv a license to display the preprint in

All rights reserved. No reuse allowed without permission.

71. Hill J.A. UCS, Greninger A.L, Shadman M, Gopal AK. Immunogenicity of a heterologous COVID-19 vaccine after failed vaccination in a lymphoma patient. Cancer Cell. 2021.

72. Prevention CfDCa. COVID-19 Vaccines for Moderately to Severely Immunocompromised People. Vol. 2021; 2021.

73. Experts WHOSAGo. WHO advisory group recommends extra COVID-19 vaccine dose for immunocompromised; 2021.

74. Halasa NB, Savani BN, Asokan I, et al. Randomized Double-Blind Study of the Safety and Immunogenicity of Standard-Dose Trivalent Inactivated Influenza Vaccine versus HighDose Trivalent Inactivated Influenza Vaccine in Adult Hematopoietic Stem Cell Transplantation Patients. Biol Blood Marrow Transplant. 2016;22(3):528-535.

75. Cohen MS, Nirula A, Mulligan MJ, et al. Effect of Bamlanivimab vs Placebo on Incidence of COVID-19 Among Residents and Staff of Skilled Nursing and Assisted Living Facilities: A Randomized Clinical Trial. JAMA. 2021;326(1):46-55.

76. Dagotto G, Yu J, Barouch DH. Approaches and Challenges in SARS-CoV-2 Vaccine Development. Cell Host Microbe. 2020;28(3):364-370.

77. Flanagan KL, Best E, Crawford NW, et al. Progress and Pitfalls in the Quest for Effective SARS-CoV-2 (COVID-19) Vaccines. Front Immunol. 2020;11:579250.

78. Khoury DS, Cromer D, Reynaldi A, et al. Neutralizing antibody levels are highly predictive of immune protection from symptomatic SARS-CoV-2 infection. Nat Med. 2021;27(7):1205-1211. 


\begin{tabular}{|c|c|c|c|c|c|c|c|c|c|c|}
\hline \multicolumn{11}{|c|}{ Mixed group studies } \\
\hline Study & $\begin{array}{l}\text { Type } \\
\text { /Location }\end{array}$ & $\begin{array}{l}\text { Study } \\
\text { population/ } \\
\text { Comparator }\end{array}$ & $\begin{array}{l}\text { Number of } \\
\text { participants } \\
\text { (analysed) }\end{array}$ & $\begin{array}{l}\text { Age } \\
\text { Median }\end{array}$ & $\begin{array}{l}\text { Male/ } \\
\text { Female }\end{array}$ & Vaccine type & Analysis & Seropositivity & $\begin{array}{l}\text { Rate of } \\
\text { positive } \\
\text { neutralising } \\
\text { antibody/ } \\
\text { cellular } \\
\text { response }\end{array}$ & $\begin{array}{l}\text { Adverse } \\
\text { events }\end{array}$ \\
\hline $\begin{array}{l}\text { Addeo et. } \\
\text { al. }{ }^{23}\end{array}$ & $\begin{array}{l}\text { Multicentre } \\
\text { prospective } \\
\text { cohort study } \\
\text { Europe, North } \\
\text { America }\end{array}$ & $\begin{array}{l}\text { Haematology } \\
\text { Solid tumour }\end{array}$ & $\begin{array}{l}25 \text { patients } \\
106 \text { patients }\end{array}$ & $\begin{array}{l}\text { Not } \\
\text { specified } \\
\text { for haem. }\end{array}$ & $\begin{array}{l}\text { Not } \\
\text { specified for } \\
\text { haem. }\end{array}$ & $\begin{array}{l}\text { BNT162b2 } \\
\text { mRNA-1273 } \\
\text { Not } \\
\text { specified for } \\
\text { haem. }\end{array}$ & $\begin{array}{l}\text { SARS-CoV-2 } \\
\text { S IgG } \\
\text { Roche } \\
\geq 0.8 \mathrm{IU} / \mathrm{ml} \\
=\text { positive }\end{array}$ & $\begin{array}{l}\text { Haematology } \\
\text { 3-4 weeks } \\
\text { post first } \\
\text { dose: } \\
\text { 18/25 (72\%) } \\
\text { 3-4 weeks } \\
\text { post second } \\
\text { dose: } \\
\text { 17/22 (77\%) } \\
\text { Solid tumour } \\
\text { First dose: } \\
80 / 96 \text { (83\%) } \\
\text { Second dose: } \\
99 / 101 \text { (98\%) }\end{array}$ & $\begin{array}{l}\text { Not } \\
\text { reported }\end{array}$ & Not reported \\
\hline $\begin{array}{l}\text { Agha et. } \\
\text { al. }^{24}\end{array}$ & $\begin{array}{l}\text { Single centre } \\
\text { retrospective } \\
\text { cohort study }\end{array}$ & Haematology & 67 patients & $\begin{array}{l}71 \text { years } \\
\text { (IQR 65- } \\
77)\end{array}$ & $\begin{array}{l}35 \text { Male } \\
32 \text { Female }\end{array}$ & $\begin{array}{l}\text { BNT162b2 } \\
\text { mRNA-1273 } \\
51 \% \\
42 \% \\
7 \% \text { unknown }\end{array}$ & $\begin{array}{l}\text { SARS-CoV-2 } \\
\text { S IgG } \\
\text { Beckman } \\
\text { Coulter } \\
\geq 1.00= \\
\text { positive }\end{array}$ & $\begin{array}{l}21 \text { days post } \\
\text { second dose: } \\
36 / 67(54 \%)\end{array}$ & $\begin{array}{l}\text { Not } \\
\text { reported }\end{array}$ & Not reported \\
\hline $\begin{array}{l}\text { Benda et. } \\
\text { al. }^{25}\end{array}$ & $\begin{array}{l}\text { Single centre } \\
\text { prospective } \\
\text { cohort study }\end{array}$ & Haematology & $\begin{array}{l}123 \text { patients } \\
-34 \% \\
\text { Myeloma }\end{array}$ & $\begin{array}{l}\text { Not } \\
\text { reported } \\
\text { in haem }\end{array}$ & $\begin{array}{l}\text { Not } \\
\text { reported in } \\
\text { haem }\end{array}$ & BNT162b2 & $\begin{array}{l}\text { SARS-CoV-2 } \\
\text { S IgG } \\
\text { Roche }\end{array}$ & $\begin{array}{l}21 \text { days post } \\
\text { first dose: } \\
53 / 123(43 \%)\end{array}$ & $\begin{array}{l}\text { Not } \\
\text { reported }\end{array}$ & $\begin{array}{l}\text { Not reported } \\
\text { for } \\
\text { haematology }\end{array}$ \\
\hline
\end{tabular}




\begin{tabular}{|c|c|c|c|c|c|c|c|c|c|c|}
\hline & Austria & Solid tumour & $\begin{array}{l}-38 \% \\
\text { CLL/lympho } \\
\text { ma/WM } \\
-28 \% \\
\text { AML/MDS/ } \\
\text { MPN } \\
136 \text { patients }\end{array}$ & & & & $\begin{array}{l}\geq 0.8 \mathrm{IU} / \mathrm{ml} \\
=\text { positive }\end{array}$ & $\begin{array}{l}28 \text { days post } \\
\text { second dose: } \\
85 / 119(71 \%)\end{array}$ & & \\
\hline $\begin{array}{l}\text { Cohen et. } \\
\text { al. }{ }^{26}\end{array}$ & $\begin{array}{l}\text { Single centre } \\
\text { retrospective } \\
\text { study } \\
\text { Israel }\end{array}$ & Haematology & 54 patients & $\begin{array}{l}69 \text { years } \\
\text { (IQR 61- } \\
77)\end{array}$ & $\begin{array}{l}32 \text { Male } \\
22 \text { Female }\end{array}$ & BNT162b2 & $\begin{array}{l}\text { SARS-CoV-2 } \\
\text { S IgG } \\
\text { Roche } \\
\geq 0.8 \mathrm{IU} / \mathrm{ml} \\
=\text { positive }\end{array}$ & $\begin{array}{l}2-3 \text { weeks } \\
\text { post second } \\
\text { dose: } \\
34 / 54(63 \%)\end{array}$ & $\begin{array}{l}\text { Not } \\
\text { reported }\end{array}$ & Not reported \\
\hline $\begin{array}{l}\text { Gavriatopo } \\
\text { ulou et. } \\
\text { al. }{ }^{27}\end{array}$ & $\begin{array}{l}\text { Single centre } \\
\text { prospective } \\
\text { cohort study } \\
\text { Greece }\end{array}$ & $\begin{array}{l}\text { Haematology } \\
\text { Control group }\end{array}$ & $\begin{array}{l}58 \text { patients } \\
-48 \% \mathrm{WM} \\
-38 \% \mathrm{CLL} \\
-14 \% \mathrm{NHL} \\
\\
213 \text { controls }\end{array}$ & $\begin{array}{l}75 \text { years } \\
(40-88)\end{array}$ & $\begin{array}{l}28 \text { Male } \\
30 \text { Female }\end{array}$ & $\begin{array}{l}\text { BNT162b2 } \\
\text { ChAdOx1 } \\
76 \% \\
24 \%\end{array}$ & $\begin{array}{l}\text { Neutralisin } \\
\text { g antibody } \\
\text { Genescript } \\
\geq 30 \%= \\
\text { positive } \\
\geq 50 \%= \\
\text { clinically } \\
\text { relevant } \\
\text { inhibition }\end{array}$ & $\begin{array}{l}22 \text { days post } \\
\text { first dose: } \\
\geq 30 \% \\
8 / 58(14 \%) \\
\text { patients } \\
\text { vs } \\
114 / 213 \\
(54 \%) \\
\text { controls }\end{array}$ & $\begin{array}{l}22 \text { days post } \\
\text { first dose: } \\
\geq 50 \% \\
3 / 58(5 \%) \\
\text { patients } \\
\text { vs. } \\
50 / 213 \\
(24 \%) \\
\text { controls }\end{array}$ & Not reported \\
\hline $\begin{array}{l}\text { Greenberg } \\
\text { er et. al. }{ }^{28}\end{array}$ & $\begin{array}{l}\text { Multicentre } \\
\text { prospective } \\
\text { cohort study }\end{array}$ & Haematology & $\begin{array}{l}1445 \\
\text { patients } \\
-45 \% \mathrm{CLL} \\
-25 \% \mathrm{NHL} \\
-5 \% \mathrm{HL} \\
-15 \% \mathrm{MM} \\
-4 \% \text { acute } \\
\text { leukaemia } \\
-2 \% \mathrm{CML} \\
-2 \% \mathrm{MPN} \\
-2 \% \text { others }\end{array}$ & $\begin{array}{l}68 \text { years } \\
(16-110)\end{array}$ & $\begin{array}{l}574 \text { Male } \\
871 \text { Female }\end{array}$ & $\begin{array}{l}\text { BNT162b2 } \\
\text { mRNA-1273 } \\
45 \% \\
55 \%\end{array}$ & $\begin{array}{l}\text { SARS-CoV-2 } \\
\text { S IgG } \\
\text { Roche } \\
\geq 0.8 \mathrm{IU} / \mathrm{ml} \\
=\text { positive }\end{array}$ & $\begin{array}{l}>14 \text { days post } \\
\text { second dose: } \\
1088 / 1445 \\
(75 \%)\end{array}$ & $\begin{array}{l}\text { Not } \\
\text { reported }\end{array}$ & Not reported \\
\hline
\end{tabular}




\begin{tabular}{|c|c|c|c|c|c|c|c|c|c|c|}
\hline $\begin{array}{l}\text { Herzog } \\
\text { Tzarfati et. } \\
\text { al. }{ }^{29}\end{array}$ & $\begin{array}{l}\text { Single centre } \\
\text { prospective } \\
\text { cohort study } \\
\text { Israel }\end{array}$ & $\begin{array}{l}\text { Haematology } \\
\text { Matched } \\
\text { Healthy } \\
\text { control }\end{array}$ & $\begin{array}{l}315 \text { patients } \\
-22 \% \text { MPN } \\
-17 \% \\
\text { Myeloma } \\
-16 \% \\
\text { aggressive } \\
\text { NHL } \\
-13 \% \\
\text { indolent } \\
\text { NHL } \\
-11 \% \mathrm{CLL} \\
-7 \% \mathrm{CML} \\
-5 \% \mathrm{HL} \\
-5 \% \text { Acute } \\
\text { leukemia } \\
-5 \% \text { MDS } \\
\end{array}$ & $\begin{array}{l}70 \text { years } \\
\text { (IQR 61- } \\
77)\end{array}$ & $\begin{array}{l}223 \text { Male } \\
200 \text { Female }\end{array}$ & BNT162b2 & $\begin{array}{l}\text { SARS-CoV-2 } \\
\text { S IgG } \\
\text { DiaSorin } \\
\geq 12 \mathrm{AU} / \mathrm{ml} \\
=\text { positive }\end{array}$ & $\begin{array}{l}30-60 \text { days } \\
\text { post second } \\
\text { dose: } \\
235 / 315 \\
(75 \%) \\
\text { vs. } \\
107 / 108 \\
(99 \%) \text { control }\end{array}$ & $\begin{array}{l}\text { Not } \\
\text { reported }\end{array}$ & Not reported \\
\hline $\begin{array}{l}\text { lacano et. } \\
\text { al. }{ }^{30}\end{array}$ & $\begin{array}{l}\text { Single centre } \\
\text { prospective } \\
\text { cohort study } \\
\text { Italy }\end{array}$ & $\begin{array}{l}\text { Haematology } \\
\geq 80 \text { years } \\
\text { Control health } \\
\text { care workers } \\
\geq 66 \text { years } \\
\text { (results not } \\
\text { reported) }\end{array}$ & 10 patients & $\begin{array}{l}\text { Not } \\
\text { specified } \\
\text { for haem }\end{array}$ & $\begin{array}{l}\text { Not } \\
\text { specified for } \\
\text { haem }\end{array}$ & BNT162b2 & $\begin{array}{l}\text { SARS-CoV-2 } \\
\text { S IgG } \\
\text { Abbott } \\
\geq 50 \mathrm{AU} / \mathrm{ml} \\
=\text { positive }\end{array}$ & $\begin{array}{l}28 \text { days post } \\
\text { second dose: } \\
4 / 10(40 \%)\end{array}$ & $\begin{array}{l}\text { Not } \\
\text { reported }\end{array}$ & Not reported \\
\hline $\begin{array}{l}\text { Jurgens et. } \\
\text { al. }\end{array}$ & $\begin{array}{l}\text { Single centre } \\
\text { prospective } \\
\text { cohort study }\end{array}$ & Haematology & $\begin{array}{l}67 \text { patients } \\
-31 \% \mathrm{CLL} \\
-63 \% \mathrm{NHL} \\
-6 \% \mathrm{HL}\end{array}$ & $\begin{array}{l}71 \text { years } \\
(24-90)\end{array}$ & $\begin{array}{l}36 \text { Male } \\
31 \text { Female }\end{array}$ & $\begin{array}{l}\text { BNT162b2 } \\
\text { mRNA-1273 } \\
46 \%\end{array}$ & $\begin{array}{l}\text { SARS-CoV-2 } \\
\text { S IgG } \\
\text { 'in house' }\end{array}$ & $\begin{array}{l}21 \text { days post } \\
\text { second dose: } \\
41 / 67(61 \%) \\
\text { vs. }\end{array}$ & $\begin{array}{l}\text { Not } \\
\text { reported }\end{array}$ & Not reported \\
\hline
\end{tabular}




\begin{tabular}{|c|c|c|c|c|c|c|c|c|c|c|}
\hline & United States & $\begin{array}{l}\text { Control health } \\
\text { care workers }\end{array}$ & 35 controls & & & $54 \%$ & $\begin{array}{l}\text { OD450 } \geq 3 \\
=\text { positive }\end{array}$ & $\begin{array}{l}35 / 35(100 \%) \\
\text { controls }\end{array}$ & & \\
\hline $\begin{array}{l}\text { Maneikis } \\
\text { et. al. }{ }^{32}\end{array}$ & $\begin{array}{l}\text { Multicentre } \\
\text { prospective } \\
\text { cohort study } \\
\text { Europe }\end{array}$ & $\begin{array}{l}\text { Haematology } \\
\text { Control - } \\
\text { Healthcare } \\
\text { workers }\end{array}$ & $\begin{array}{l}857 \text { patients } \\
68 \text { controls }\end{array}$ & $\begin{array}{l}65 \text { years } \\
\text { (IQR 54- } \\
72)\end{array}$ & $\begin{array}{l}404 \text { Male } \\
453 \text { Female }\end{array}$ & BNT162b2 & $\begin{array}{l}\text { SARS-CoV-2 } \\
\text { S IgG } \\
\text { Abbott } \\
\geq 50 \mathrm{AU} / \mathrm{ml} \\
=\text { positive }\end{array}$ & $\begin{array}{l}7-21 \text { days post } \\
\text { first dose: } \\
481 / 857 \\
(56 \%) \\
\text { Not reported } \\
\text { for control } \\
\text { group }\end{array}$ & $\begin{array}{l}\text { Not } \\
\text { reported }\end{array}$ & $\begin{array}{l}\text { At least } 1 \\
\text { adverse } \\
\text { event: } \\
56 / 575(9 \%) \\
\text { dose } 1 \\
72 / 575(13 \%) \\
\text { dose } 2\end{array}$ \\
\hline $\begin{array}{l}\text { Malard et. } \\
\text { al. }^{33}\end{array}$ & $\begin{array}{l}\text { Single centre } \\
\text { retrospective } \\
\text { cohort study } \\
\text { France }\end{array}$ & $\begin{array}{l}\text { Haematology } \\
\text { Healthy } \\
\text { controls }\end{array}$ & $\begin{array}{l}195 \text { patients } \\
-27 \% \\
\text { myeloma } \\
-23 \% \mathrm{NHL} \\
-3 \% \mathrm{HL} \\
-13 \% \mathrm{CLL} \\
-16 \% \mathrm{AML} \\
-2 \% \mathrm{ALL} \\
-9 \% \mathrm{MPN} \\
-7 \% \text { others }\end{array}$ & $\begin{array}{l}69 \text { years } \\
(22-92)\end{array}$ & $\begin{array}{l}117 \text { Male } \\
78 \text { Female }\end{array}$ & BNT162b2 & $\begin{array}{l}\text { SARS-CoV-2 } \\
\text { S IgG } \\
\text { Abbott } \\
\geq 50 \mathrm{AU} / \mathrm{ml} \\
=\text { positive } \\
\geq 3100 \\
\mathrm{AU} / \mathrm{ml}= \\
\text { neutralisati } \\
\text { on }>30 \% \\
\text { SARS-CoV-2 } \\
\text { T cell } \\
\text { response } \\
\text { ELISPOT } \\
\geq 10 \text { spot } \\
\text { forming } \\
\text { cells } / 10^{6} \\
\text { PBMCs and } \\
\text { ratio } 2.5= \\
\text { positive }\end{array}$ & $\begin{array}{l}\geq 3100 \mathrm{AU} / \mathrm{ml} \\
\text { Threshold* } \\
28 \text { days post } \\
\text { first dose: } \\
3 / 195(2 \%) \\
14 \text { days post } \\
\text { second dose: } \\
91 / 196(47 \%) \\
\text { vs. } \\
26 / 30(87 \%) \\
\text { controls }\end{array}$ & $\begin{array}{l}\text { Cellular } \\
\text { response } \\
14 \text { days post } \\
\text { second } \\
\text { dose: } \\
36 / 68(53 \%)\end{array}$ & $\begin{array}{l}\text { At least } 1 \\
\text { adverse } \\
\text { event: } \\
88 / 154(57 \%) \\
\text { Dose } 1 \\
55 / 163(34 \%) \\
\text { Dose } 2\end{array}$ \\
\hline
\end{tabular}




\begin{tabular}{|c|c|c|c|c|c|c|c|c|c|c|}
\hline $\begin{array}{l}\text { Monin et. } \\
\text { al. }^{34}\end{array}$ & $\begin{array}{l}\text { Multicentre } \\
\text { prospective } \\
\text { cohort study } \\
\text { United } \\
\text { Kingdom }\end{array}$ & $\begin{array}{l}\text { Haematology } \\
\\
\text { Health care } \\
\text { workers } \\
\text { controls }\end{array}$ & $\begin{array}{l}56 \text { patients } \\
-68 \% \text { B cell } \\
\text { malignancy } \\
-9 \% \text { T cell } \\
\text { malignancy } \\
-18 \% \\
\text { myeloid/acu } \\
\text { te leukaemia } \\
-5 \% \text { others } \\
\\
54 \text { controls }\end{array}$ & $\begin{array}{l}73 \text { years } \\
\text { (IQR 65- } \\
80)\end{array}$ & $\begin{array}{l}\text { Not } \\
\text { extractable } \\
\text { for haem }\end{array}$ & BNT162b2 & $\begin{array}{l}\text { SARS-CoV-2 } \\
\text { Spike IgG } \\
\geq 70 \mathrm{EC}_{50}= \\
\text { positive } \\
\text { SARS-CoV-2 } \\
\text { specific T } \\
\text { cells } \\
\text { secreting } \\
\text { IFN-gamma } \\
\text { and/or IL2 } \\
>7 \\
\text { cytokine- } \\
\text { secreting } \\
\text { cells per } \\
10^{6} \text { PBMC } \\
=\text { positive }\end{array}$ & $\begin{array}{l}21 \text { days post } \\
\text { first dose: } \\
8 / 44 \text { (18\%) } \\
\text { vs. } \\
32 / 34 \text { ( } 94 \%) \\
\text { Controls } \\
35 \text { days post } \\
\text { first dose: } \\
4 / 36 \text { (11\%) } \\
\text { vs. } \\
18 / 21 \text { ( } 86 \%) \\
\text { controls } \\
35 \text { days post } \\
\text { first dose } \\
\text { (with second } \\
\text { dose): } \\
3 / 5 \text { (60\%) } \\
\text { vs. } \\
12 / 12 \text { (100\%) } \\
\text { controls }\end{array}$ & $\begin{array}{l}\text { Cellular } \\
\text { response } \\
21 \text { days post } \\
\text { first dose: } \\
9 / 18(50 \%) \\
\text { vs. } \\
14 / 17 \text { ( } 82 \%) \\
\text { controls } \\
35 \text { days post } \\
\text { first dose: } \\
6 / 18 \text { (33\%) } \\
\text { vs. } \\
9 / 13 \text { (69\%) } \\
\text { controls } \\
35 \text { days post } \\
\text { first dose } \\
\text { (with second } \\
\text { dose): } \\
3 / 4 \text { ( } 75 \%) \\
\text { vs. } \\
3 / 3 \text { (100\%) } \\
\text { controls }\end{array}$ & $\begin{array}{l}\text { Not } \\
\text { extractable } \\
\text { for } \\
\text { haematology } \\
\text { patients }\end{array}$ \\
\hline $\begin{array}{l}\text { Ollila et. } \\
\text { al. }^{35}\end{array}$ & 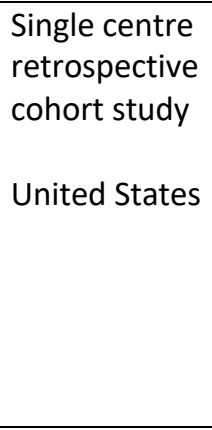 & Haematology & $\begin{array}{l}160 \text { patients } \\
-36 \% \\
\text { aggressive } \\
\text { lymphoma } \\
-21 \% \\
\text { indolent } \\
\text { lymphoma } \\
-15 \% \text { plasma } \\
\text { cell } \\
-12 \% \text { CLL }\end{array}$ & $\begin{array}{l}72 \text { years } \\
(65-79)\end{array}$ & $\begin{array}{l}86 \text { Male } \\
74 \text { Female }\end{array}$ & $\begin{array}{l}\text { BNT162b2 } \\
\text { mRNA-1273 } \\
\text { Ad26 } \\
60 \% \\
31 \% \\
7 \% \\
1 \% \text { - not } \\
\text { determined }\end{array}$ & $\begin{array}{l}\text { SARS-CoV-2 } \\
\text { S IgG } \\
\text { Abbott } \\
\text { Signal/cuto } \\
\text { ff ratio } \geq 1.4 \\
=\text { positive }\end{array}$ & $\begin{array}{l}56 \text { days post } \\
\text { first dose: } \\
63 / 160(39 \%)\end{array}$ & $\begin{array}{l}\text { Not } \\
\text { reported }\end{array}$ & Not reported \\
\hline
\end{tabular}




\begin{tabular}{|c|c|c|c|c|c|c|c|c|c|c|}
\hline & & & $\begin{array}{l}-9 \% \text { other } \\
\text { lymphoma } \\
-6 \% \text { myeloid }\end{array}$ & & & & & & & \\
\hline $\begin{array}{l}\text { Pimpinelli } \\
\text { et. al. }{ }^{36}\end{array}$ & $\begin{array}{l}\text { Single centre } \\
\text { prospective } \\
\text { study } \\
\text { Italy }\end{array}$ & $\begin{array}{l}\text { Haematology } \\
\text {-Myeloma } \\
\text {-MPN } \\
\\
\text { Older age (> } \\
80 \text { years) } \\
\text { control group }\end{array}$ & $\begin{array}{l}92 \text { patients } \\
-46 \% \\
\text { myeloma } \\
-54 \% \text { MPN } \\
36 \text { controls }\end{array}$ & $\begin{array}{l}73 \text { years } \\
(47-78) \\
70 \text { years } \\
(28-80)\end{array}$ & $\begin{array}{l}\text { Myeloma } \\
23 \text { Male } \\
19 \text { Female } \\
\text { MPN } \\
26 \text { Male } \\
24 \text { Female }\end{array}$ & BNT162b2 & $\begin{array}{l}\text { SARS-CoV-2 } \\
\text { S IgG } \\
\text { DiaSorin } \\
\geq 15 \mathrm{AU} / \mathrm{ml} \\
=\text { positive }\end{array}$ & $\begin{array}{l}21 \text { days post } \\
\text { first dose: } \\
9 / 42(21 \%) \\
\text { myeloma } \\
26 / 50(52 \%) \\
\text { MPN } \\
\text { vs. } \\
19 / 36(53 \%) \\
\text { controls } \\
14 \text { days post } \\
\text { second dose: } \\
33 / 42 \text { (79\%) } \\
\text { myeloma } \\
44 / 50(88 \%) \\
\text { MPN } \\
\text { vs. } 36 / 36 \\
\text { (100\%) } \\
\text { controls } \\
\geq 80 \text { AU/ml } \\
\text { threshold* } \\
14 \text { days post } \\
\text { second dose } \\
23 / 42 \text { (55\%) } \\
\text { myeloma } \\
42 / 50 \text { (84\%) } \\
\text { MPN } \\
\text { vs. } \\
34 / 36(97 \%) \\
\text { control }\end{array}$ & $\begin{array}{l}\text { Not } \\
\text { reported }\end{array}$ & $\begin{array}{l}\text { Reported } \\
\text { with different } \\
\text { patient } \\
\text { numbers }\end{array}$ \\
\hline
\end{tabular}




\begin{tabular}{|c|c|c|c|c|c|c|c|c|c|c|}
\hline Re et. al. ${ }^{37}$ & $\begin{array}{l}\text { Multicentre } \\
\text { retrospective } \\
\text { cohort study } \\
\text { France }\end{array}$ & Haematology & $\begin{array}{l}102 \text { patients } \\
-45 \% \\
\text { lymphoma } \\
-22 \% \\
\text { myeloma } \\
-13 \% \\
\text { MDS/AML } \\
-10 \% \text { CLL } \\
-10 \% \text { MPN }\end{array}$ & $\begin{array}{l}76 \text { years } \\
(33-93)\end{array}$ & $\begin{array}{l}67 \text { Male } \\
35 \text { Female }\end{array}$ & $\begin{array}{l}\text { BNT162b2 } \\
\text { mRNA-1273 } \\
93 \% \\
7 \%\end{array}$ & $\begin{array}{l}\text { SARS-CoV-2 } \\
\text { S IgG } \\
\text { Range of } \\
\text { commercial } \\
\text { kits utilising } \\
\text { their } \\
\text { threshold }\end{array}$ & $\begin{array}{l}21-28 \text { days } \\
\text { post second } \\
\text { dose } \\
64 / 102(62 \%)\end{array}$ & $\begin{array}{l}\text { Not } \\
\text { reported }\end{array}$ & Not reported \\
\hline $\begin{array}{l}\text { Thakkar et. } \\
\text { al. }^{38}\end{array}$ & $\begin{array}{l}\text { Single centre } \\
\text { prospective } \\
\text { and } \\
\text { retrospective } \\
\text { cohort study } \\
\text { United States }\end{array}$ & $\begin{array}{l}\text { Haematology } \\
\text { Solid tumours } \\
\text { Healthy } \\
\text { control } \\
\end{array}$ & $\begin{array}{l}66 \text { patients } \\
-39 \% \\
\text { lymphoid } \\
-27 \% \\
\text { myeloid } \\
-33 \% \text { plasma } \\
\text { cell } \\
134 \text { patients } \\
26 \text { controls }\end{array}$ & $\begin{array}{l}\text { Not } \\
\text { reported } \\
\text { for haem }\end{array}$ & $\begin{array}{l}\text { Not } \\
\text { reported for } \\
\text { haem }\end{array}$ & $\begin{array}{l}\text { BNT162b2 } \\
\text { mRNA-1273 } \\
\text { Ad26 } \\
58 \% \\
31 \% \\
10 \% \\
2 \% \text { mRNA } \\
\text { type } \\
\text { unknown }\end{array}$ & $\begin{array}{l}\text { SARS-CoV-2 } \\
\text { S IgG } \\
\text { Abbott } \\
\geq 50 \mathrm{AU} / \mathrm{ml} \\
=\text { positive }\end{array}$ & $\begin{array}{l}>7 \text { days after } \\
\text { second dose: } \\
56 / 66(85 \%) \\
\text { vs. } \\
131 / 134 \\
(98 \%) \text { solid } \\
\text { tumours } \\
\text { Rate not } \\
\text { reported for } \\
\text { controls }\end{array}$ & $\begin{array}{l}\text { Not } \\
\text { reported }\end{array}$ & $\begin{array}{l}\text { Not reported } \\
\text { for } \\
\text { haematology }\end{array}$ \\
\hline \multicolumn{11}{|c|}{ Myeloma specific studies } \\
\hline $\begin{array}{l}\text { Avivi et. } \\
\text { al. }^{39}\end{array}$ & $\begin{array}{l}\text { Single centre } \\
\text { Prospective } \\
\text { cohort study } \\
\text { Israel }\end{array}$ & $\begin{array}{l}\text { Myeloma } \\
\text { Healthy } \\
\text { volunteers }\end{array}$ & $\begin{array}{l}171 \text { patients } \\
64 \\
\text { controls }\end{array}$ & $\begin{array}{l}70 \text { years } \\
(38-94)\end{array}$ & $\begin{array}{l}96 \text { Male } \\
75 \text { Female }\end{array}$ & BNT162b2 & $\begin{array}{l}\text { SARS-CoV-2 } \\
\text { S IgG } \\
\text { Roche } \\
\geq 0.8 \mathrm{UI} / \mathrm{ml} \\
=\text { positive }\end{array}$ & $\begin{array}{l}\text { 14-21 days } \\
\text { post second } \\
\text { dose: } \\
133 / 171 \\
(78 \%) \\
\text { vs. } \\
63 / 64(98 \%) \\
\text { controls }\end{array}$ & $\begin{array}{l}\text { Not } \\
\text { reported }\end{array}$ & $\begin{array}{l}\text { At least one } \\
\text { adverse } \\
\text { event: } \\
90 / 161(53 \%) \\
\text { vs. } \\
29 / 53(55 \%) \\
\text { controls }\end{array}$ \\
\hline $\begin{array}{l}\text { Bird et. } \\
\text { al. }^{40}\end{array}$ & $\begin{array}{l}\text { Single centre } \\
\text { retrospective } \\
\text { cohort study }\end{array}$ & Myeloma & 93 patients & $\begin{array}{l}67 \text { years } \\
(47-87)\end{array}$ & $\begin{array}{l}55 \text { Male } \\
38 \text { Female }\end{array}$ & $\begin{array}{l}\text { BNT162b2 } \\
\text { ChAdOx1 }\end{array}$ & $\begin{array}{l}\text { SARS-CoV-2 } \\
\text { S IgG }\end{array}$ & $\begin{array}{l}\geq 21 \text { days } \\
\text { post first } \\
\text { dose: }\end{array}$ & $\begin{array}{l}\text { Not } \\
\text { reported }\end{array}$ & Not reported \\
\hline
\end{tabular}




\begin{tabular}{|c|c|c|c|c|c|c|c|c|c|c|}
\hline & $\begin{array}{l}\text { United } \\
\text { Kingdom }\end{array}$ & & & & & $52 \% / 48 \%$ & $\begin{array}{l}\text { Ortho } \\
\text { clinical } \\
\geq 1 \\
\text { signal/cut- } \\
\text { off = } \\
\text { positive }\end{array}$ & $52 / 93$ (56\%) & & \\
\hline $\begin{array}{l}\text { Ghandili } \\
\text { et. al. }{ }^{41}\end{array}$ & $\begin{array}{l}\text { Single centre } \\
\text { prospective } \\
\text { cohort study } \\
\text { Germany }\end{array}$ & Myeloma & 82 patients & $\begin{array}{l}68 \text { years } \\
(40-85)\end{array}$ & $\begin{array}{l}49 \text { Male } \\
33 \text { Female }\end{array}$ & $\begin{array}{l}\text { BNT162b2 } \\
\text { ChAdOx1 } \\
77 \% \\
23 \%\end{array}$ & $\begin{array}{l}\text { SARS-CoV-2 } \\
\text { S IgG } \\
\text { DiaSorin } \\
\geq 34 \mathrm{AU} / \mathrm{ml} \\
=\text { positive }\end{array}$ & $\begin{array}{l}21 \text { days post } \\
\text { first dose: } \\
17 / 74(23 \%)\end{array}$ & $\begin{array}{l}\text { Not } \\
\text { reported }\end{array}$ & Not reported \\
\hline $\begin{array}{l}\text { Ramasamy } \\
\text { et. al. }{ }^{42}\end{array}$ & $\begin{array}{l}\text { Multicentre } \\
\text { web-based } \\
\text { prospective } \\
\text { cohort study } \\
\text { United } \\
\text { Kingdom }\end{array}$ & Myeloma & $\begin{array}{l}105 \text { patients } \\
-28 \text { patients } \\
\text { sampled }\end{array}$ & 63 years & $\begin{array}{l}67 \text { Male } \\
42 \text { Female }\end{array}$ & $\begin{array}{l}\text { BNT162b2 } \\
\text { ChAdOx1 } \\
42 \% \\
58 \%\end{array}$ & $\begin{array}{l}\text { SARS-CoV-2 } \\
\text { S IgG } \\
\text { Abbott } \\
\text { COI } \geq 50= \\
\text { positive }\end{array}$ & $\begin{array}{l}>21 \text { days post } \\
\text { first dose: } \\
17 / 28(61 \%)\end{array}$ & $\begin{array}{l}\text { Not } \\
\text { reported }\end{array}$ & Not reported \\
\hline $\begin{array}{l}\text { Stampfer } \\
\text { et. al. }{ }^{43}\end{array}$ & $\begin{array}{l}\text { Single centre } \\
\text { prospective } \\
\text { cohort study }\end{array}$ & $\begin{array}{l}\text { Myeloma } \\
\text { Healthy } \\
\text { controls } \\
\text { Pre-COVID-19 } \\
\text { controls }\end{array}$ & $\begin{array}{l}103 \text { patients } \\
31 \text { controls } \\
34 \text { controls }\end{array}$ & $\begin{array}{l}68 \text { years } \\
(35-88)\end{array}$ & $\begin{array}{l}61 \text { Male } \\
42 \text { Female }\end{array}$ & $\begin{array}{l}\text { BNT162b2 } \\
\text { mRNA-1273 } \\
50 \% \\
50 \%\end{array}$ & $\begin{array}{l}\text { SARS-CoV-2 } \\
\text { S IgG } \\
\text { 'in house' } \\
50-250 \\
\mathrm{IU} / \mathrm{ml}= \\
\text { positive } \\
\text { (partial } \\
\text { response) } \\
>250 \mathrm{IU} / \mathrm{ml} \\
=\text { clinically } \\
\text { relevant } \\
\text { response }\end{array}$ & $\begin{array}{l}\text { 14-21 days } \\
\text { post first } \\
\text { dose: } \\
20 / 93(22 \%) \\
14-21 \text { days } \\
\text { post second } \\
\text { dose: } \\
64 / 96(67 \%) \\
\text { vs. } \\
31 / 31(100 \%) \\
\text { controls }\end{array}$ & $\begin{array}{l}\text { Not } \\
\text { reported }\end{array}$ & Not reported \\
\hline
\end{tabular}




\begin{tabular}{|c|c|c|c|c|c|c|c|c|c|c|}
\hline & & & & & & & & $\begin{array}{l}>250 \mathrm{IU} / \mathrm{ml} \\
14-21 \text { days } \\
\text { post first } \\
\text { dose: } \\
2 / 93(2 \%) \\
14-21 \text { days } \\
\text { post second } \\
\text { dose: } \\
43 / 93(46 \%) \\
\text { vs. } \\
29 / 31(94 \%) \\
\text { controls }\end{array}$ & & \\
\hline $\begin{array}{l}\text { Terpos et. } \\
\text { al. }^{44}\end{array}$ & $\begin{array}{l}\text { Single centre } \\
\text { prospective } \\
\text { cohort study } \\
\text { Greece }\end{array}$ & $\begin{array}{l}\text { Myeloma } \\
\text { Matched } \\
\text { Controls }\end{array}$ & $\begin{array}{l}48 \text { patients } \\
102 \text { controls }\end{array}$ & $\begin{array}{l}83 \text { years } \\
(59-92)\end{array}$ & $\begin{array}{l}29 \text { Male } \\
19 \text { Female }\end{array}$ & BNT162b2 & $\begin{array}{l}\text { SARS-CoV-2 } \\
\text { neutralising } \\
\mathrm{Ab} \\
\text { Genscript } \\
\geq 30 \%= \\
\text { positive } \\
\geq 50 \%= \\
\text { clinically } \\
\text { relevant }\end{array}$ & $\begin{array}{l}\geq 30 \% \\
22 \text { days post } \\
\text { first dose: } \\
12 / 48(25 \%) \\
\text { vs. } \\
57 / 102(55 \%) \\
\text { controls }\end{array}$ & $\begin{array}{l}250 \% \\
22 \text { days post } \\
\text { first dose: } \\
4 / 48(8 \%) \\
\text { vs. } \\
21 / 102 \\
(20 \%) \\
\text { controls }\end{array}$ & Not reported \\
\hline $\begin{array}{l}\text { Terpos et. } \\
\text { al. } 45\end{array}$ & $\begin{array}{l}\text { Single centre } \\
\text { prospective } \\
\text { cohort study } \\
\text { Greece }\end{array}$ & $\begin{array}{l}\text { Myeloma } \\
\text { Matched } \\
\text { Controls }\end{array}$ & $\begin{array}{l}276 \text { patients } \\
-77 \% \\
\text { myeloma } \\
-14 \% \text { sMM } \\
-9 \% \text { MGUS } \\
\\
226 \text { controls }\end{array}$ & $\begin{array}{l}74 \text { years } \\
(62-80)\end{array}$ & $\begin{array}{l}151 \text { Male } \\
125 \text { Female }\end{array}$ & $\begin{array}{l}\text { BNT162b2 } \\
\text { ChAdOx1 } \\
78 \% \\
22 \%\end{array}$ & $\begin{array}{l}\text { SARS-CoV-2 } \\
\text { neutralising } \\
\mathrm{Ab} \\
\text { Genscript } \\
\geq 30 \%= \\
\text { positive } \\
\geq 50 \%= \\
\text { clinically } \\
\text { relevant }\end{array}$ & $\begin{array}{l}\geq 30 \% \\
\text { Day } 22 \text { post } \\
\text { first dose: } \\
117 / 276 \\
(42 \%) \\
\text { vs. } \\
145 / 226 \\
(64 \%) \\
\text { controls }\end{array}$ & $\begin{array}{l}\geq 50 \% \\
\text { Day } 22 \text { post } \\
\text { first dose: } \\
55 / 276 \\
(20 \%) \\
\text { vs. } \\
73 / 226 \\
(32 \%) \\
\text { controls }\end{array}$ & $\begin{array}{l}\text { First dose } \\
\text { BNT162b2 } \\
\text { 71/215 (33\%) } \\
\text { local reaction } \\
\text { 28/215 (13\%) } \\
\text { systemic } \\
\text { reaction } \\
\text { ChAdOx1 } \\
\text { 20/61 (33\%) } \\
\text { local reaction }\end{array}$ \\
\hline
\end{tabular}




\begin{tabular}{|c|c|c|c|c|c|c|c|c|c|c|}
\hline & & & & & & & & $\begin{array}{l}\text { Day } 50 \text { post } \\
\text { first dose: } \\
196 / 276 \\
(71 \%) \\
\text { vs. } \\
204 / 226 \\
(90 \%) \\
\text { controls }\end{array}$ & $\begin{array}{l}\text { Day } 50 \text { post } \\
\text { first dose: } \\
158 / 276 \\
(57 \%) \\
\text { vs. } \\
183 / 226 \\
(81 \%) \\
\text { controls }\end{array}$ & $\begin{array}{l}\text { Second dose } \\
\text { BNT162b2 } \\
68 / 215 \text { (32\%) } \\
\text { local reaction } \\
45 / 215(21 \%) \\
\text { systemic } \\
\text { reaction }\end{array}$ \\
\hline $\begin{array}{l}\text { Van } \\
\text { Oekelen } \\
\text { et. al. }{ }^{46}\end{array}$ & $\begin{array}{l}\text { Single centre } \\
\text { prospective } \\
\text { and } \\
\text { retrospective } \\
\text { cohort study } \\
\text { United States }\end{array}$ & $\begin{array}{l}\text { Myeloma } \\
\text { Matched } \\
\text { control health } \\
\text { care workers }\end{array}$ & $\begin{array}{l}320 \text { patients } \\
-260 \\
\text { sampled } \\
\\
67 \text { controls }\end{array}$ & $\begin{array}{l}68 \text { years } \\
(38-93)\end{array}$ & $\begin{array}{l}185 \text { Male } \\
135 \text { Female }\end{array}$ & $\begin{array}{l}\text { BNT162b2 } \\
\text { mRNA-1273 } \\
\text { unknown } \\
69 \% \\
27 \% \\
4 \%\end{array}$ & $\begin{array}{l}\text { SARS-CoV-2 } \\
\text { S IgG } \\
\text { 'in house' } \\
\geq 5 \mathrm{AU} / \mathrm{ml}= \\
\text { positive }\end{array}$ & $\begin{array}{l}1 \text { days post } \\
\text { second dose: } \\
219 / 260 \\
(84 \%) \\
\text { vs. } \\
67 / 67 \\
(100 \%) \\
\text { controls }\end{array}$ & $\begin{array}{l}\text { Not } \\
\text { reported }\end{array}$ & Not reported \\
\hline \multicolumn{11}{|c|}{ CLL specific studies } \\
\hline $\begin{array}{l}\text { Benjamini } \\
\text { et. al. }{ }^{47}\end{array}$ & $\begin{array}{l}\text { Multicentre } \\
\text { prospective } \\
\text { cohort study } \\
\text { Israel }\end{array}$ & CLL patients & 373 patients & $\begin{array}{l}70 \text { years } \\
(40-89)\end{array}$ & $\begin{array}{l}222 \text { Male } \\
151 \text { Female }\end{array}$ & BNT162b2 & $\begin{array}{l}\text { SARS-CoV-2 } \\
\text { S IgG } \\
\text { DiaSorin } \\
\geq 15 \mathrm{AU} / \mathrm{ml} \\
=\text { positive } \\
\text { Abbott } \\
>50 \mathrm{U} / \mathrm{ml}= \\
\text { positive } \\
\text { 'in house' } \\
>1.1= \\
\text { positive }\end{array}$ & $\begin{array}{l}\text { 14-21 days } \\
\text { post second } \\
\text { dose: } \\
160 / 373 \\
(43 \%)\end{array}$ & $\begin{array}{l}\text { Not } \\
\text { reported }\end{array}$ & $\begin{array}{l}\text { At least } 1 \\
\text { adverse } \\
\text { event: } \\
151 / 331 \\
(47 \%)\end{array}$ \\
\hline
\end{tabular}




\begin{tabular}{|c|c|c|c|c|c|c|c|c|c|c|}
\hline $\begin{array}{l}\text { Del Poeta } \\
\text { et. al. }{ }^{48}\end{array}$ & $\begin{array}{l}\text { Single centre } \\
\text { prospective } \\
\text { cohort study } \\
\text { Italy }\end{array}$ & CLL patients & 46 patients & $\begin{array}{l}\text { Not } \\
\text { reported }\end{array}$ & $\begin{array}{l}29 \text { Male } \\
17 \text { Female }\end{array}$ & BNT162b2 & $\begin{array}{l}\text { SARS-CoV-2 } \\
\text { S IgG } \\
\text { Maglumi } \\
\geq 1.1= \\
\text { positive }\end{array}$ & $\begin{array}{l}\text { 14-21 days } \\
\text { post second } \\
\text { dose: } \\
25 / 46(54 \%)\end{array}$ & $\begin{array}{l}\text { Not } \\
\text { reported }\end{array}$ & Not reported \\
\hline $\begin{array}{l}\text { Herishanu } \\
\text { et. al. }{ }^{49}\end{array}$ & $\begin{array}{l}\text { Single centre } \\
\text { prospective } \\
\text { cohort study } \\
\text { Israel }\end{array}$ & $\begin{array}{l}\text { CLL patients } \\
\text { Control -age, } \\
\text { sex matched }\end{array}$ & $\begin{array}{l}167 \text { patients } \\
52 \text { controls }\end{array}$ & $\begin{array}{l}71 \text { years } \\
(63-76)\end{array}$ & $\begin{array}{l}112 \text { Male } \\
55 \text { Female }\end{array}$ & BNT162b2 & $\begin{array}{l}\text { SARS-CoV-2 } \\
\text { S IgG } \\
\text { Roche } \\
\geq 0.8 \mathrm{IU} / \mathrm{ml} \\
=\text { positive }\end{array}$ & $\begin{array}{l}14-21 \text { days } \\
\text { post second } \\
\text { dose: } \\
66 / 167(40 \%) \\
\text { patients } \\
\text { vs. } \\
52 / 52(100 \%) \\
\text { controls }\end{array}$ & $\begin{array}{l}\text { Not } \\
\text { reported }\end{array}$ & $\begin{array}{l}\text { First dose } \\
52 / 167 \text { (31\%) } \\
\text { local reaction } \\
21 / 167 \\
(13 \%) \\
\text { Systemic } \\
\text { reaction } \\
\text { Second dose } \\
56 / 167 \text { (34\%) } \\
\text { local reaction } \\
21 / 167 \text { (23\%) } \\
\text { Systemic } \\
\text { reaction }\end{array}$ \\
\hline $\begin{array}{l}\text { Parry et. } \\
\text { al. }^{50}\end{array}$ & $\begin{array}{l}\text { Single centre } \\
\text { prospective } \\
\text { cohort study } \\
\text { United } \\
\text { Kingdom }\end{array}$ & $\begin{array}{l}\text { CLL patients } \\
\text { Healthy age } \\
\text { matched } \\
\text { controls }\end{array}$ & $\begin{array}{l}299 \text { patients } \\
93 \text { controls }\end{array}$ & $\begin{array}{l}69 \text { years } \\
\text { (IQR 63- } \\
74)\end{array}$ & $\begin{array}{l}159 \text { Male } \\
140 \text { Female }\end{array}$ & $\begin{array}{l}\text { BNT162b2 } \\
\text { ChAxOd1 } \\
52 \% \\
48 \%\end{array}$ & $\begin{array}{l}\text { SARS-CoV-2 } \\
\text { S IgG } \\
\text { Roche } \\
\geq 0.8 \mathrm{IU} / \mathrm{ml} \\
=\text { positive } \\
\\
\text { Dried blood } \\
\text { sampling } \\
\text { Roche } \\
\text { ratio } \geq 1.0 \\
=\text { positive }\end{array}$ & $\begin{array}{l}43 \text { days post } \\
\text { first dose: } \\
\text { Serum } \\
29 / 86(34 \%) \\
\text { vs. } \\
89 / 95 \text { (94\%) } \\
\text { Control } \\
\text { Dried blood* } \\
63 / 267(24 \%) \\
\text { vs. } \\
66 / 93(71 \%) \\
\text { control }\end{array}$ & $\begin{array}{l}\text { Not } \\
\text { reported }\end{array}$ & Not reported \\
\hline
\end{tabular}




\begin{tabular}{|c|c|c|c|c|c|c|c|c|c|c|}
\hline & & & & & & & & $\begin{array}{l}18 \text { days post } \\
\text { second dose: } \\
\text { Serum } \\
9 / 12 \text { (75\%) } \\
\text { vs. } \\
59 / 59(100 \%) \\
\text { Controls } \\
\\
\text { Dried blood* } \\
39 / 55 \text { (71\%) } \\
\text { vs. } \\
36 / 37 \text { (97\%) } \\
\text { controls }\end{array}$ & & \\
\hline $\begin{array}{l}\text { Roeker et. } \\
\text { al. }{ }^{51}\end{array}$ & $\begin{array}{l}\text { Single centre } \\
\text { retrospective } \\
\text { cohort study } \\
\text { United States }\end{array}$ & CLL patients & 44 patients & $\begin{array}{l}71 \text { years } \\
(37-89)\end{array}$ & $\begin{array}{l}23 \text { Male } \\
21 \text { Female }\end{array}$ & $\begin{array}{l}\text { BNT162b2 } \\
\text { mRNA-1273 } \\
57 \% \\
43 \%\end{array}$ & $\begin{array}{l}\text { SARS-CoV-2 } \\
\text { S IgG } \\
\text { DiaSorin } \\
\geq 15 \mathrm{AU} / \mathrm{ml} \\
=\text { positive }\end{array}$ & $\begin{array}{l}21 \text { days post } \\
\text { second dose: } \\
23 / 44 \text { (52\%) }\end{array}$ & $\begin{array}{l}\text { Not } \\
\text { reported }\end{array}$ & Not reported \\
\hline $\begin{array}{l}\text { Tadmor et. } \\
\text { al. }{ }^{52}\end{array}$ & $\begin{array}{l}\text { Multicentre } \\
\text { prospective } \\
\text { observation } \\
\text { study } \\
\text { Israel }\end{array}$ & CLL patients & 84 patients & $\begin{array}{l}69 \text { years } \\
(44-87)\end{array}$ & $\begin{array}{l}53 \text { Male } \\
29 \text { Female }\end{array}$ & BNT162b2 & $\begin{array}{l}\text { SARS-CoV-2 } \\
\text { S IgG } \\
\text { Abbott } \\
\geq 50 \mathrm{U} / \mathrm{ml}= \\
\text { positive } \\
\text { SARS-CoV-2 } \\
\text { RBD IgG } \\
>1.1= \\
\text { positive }\end{array}$ & $\begin{array}{l}22 \text { days post } \\
\text { second dose: } \\
49 / 84 \text { (58\%) }\end{array}$ & $\begin{array}{l}\text { Not } \\
\text { reported }\end{array}$ & Not reported \\
\hline
\end{tabular}




\begin{tabular}{|c|c|c|c|c|c|c|c|c|c|c|}
\hline $\begin{array}{l}\text { Ghione et. } \\
\text { al. } 53\end{array}$ & 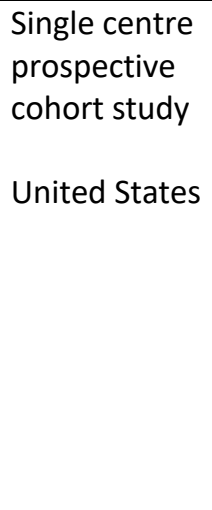 & $\begin{array}{l}\text { B-cell } \\
\text { lymphoma } \\
\text { Control } \\
\text { age-care, } \\
\text { healthcare } \\
\text { workers }\end{array}$ & $\begin{array}{l}86 \text { patients } \\
47 \text { controls } \\
154 \text { controls }\end{array}$ & $\begin{array}{l}70 \text { years } \\
(35-91)\end{array}$ & $\begin{array}{l}45 \text { Male } \\
41 \text { Female }\end{array}$ & $\begin{array}{l}\text { BNT162b2 } \\
\text { mRNA-1273 } \\
\text { Ad26 } \\
47 \% \\
52 \% \\
1 \%\end{array}$ & $\begin{array}{l}\text { SARS-CoV-2 } \\
\text { S IgG } \\
\text { BioRad } \\
\geq 1.0= \\
\text { positive }\end{array}$ & $\begin{array}{l}14-56 \text { days } \\
\text { post } \\
\text { completion of } \\
\text { vaccination: } \\
36 / 86(42 \%) \\
\text { patients } \\
\text { vs. } \\
43 / 47(92 \%) \\
\text { age-care } \\
154 / 154 \\
\text { (100\%) } \\
\text { healthcare }\end{array}$ & $\begin{array}{l}\text { Not } \\
\text { reported }\end{array}$ & Not reported \\
\hline $\begin{array}{l}\text { Gurion et. } \\
\text { al. }{ }^{54}\end{array}$ & $\begin{array}{l}\text { Multicentre } \\
\text { prospective } \\
\text { cohort study } \\
\text { Israel }\end{array}$ & Lymphoma & $\begin{array}{l}162 \text { patients } \\
-88 \% \mathrm{NHL} \\
-12 \% \mathrm{HL}\end{array}$ & $\begin{array}{l}65 \text { years } \\
(52-73)\end{array}$ & $\begin{array}{l}89 \text { Male } \\
73 \text { Female }\end{array}$ & BNT162b2 & $\begin{array}{l}\text { SARS-CoV-2 } \\
\text { S IgG } \\
\text { Abbott } \\
\geq 50 \mathrm{IU} / \mathrm{ml} \\
=\text { positive }\end{array}$ & $\begin{array}{l}28 \text { days post } \\
\text { second dose: } \\
83 / 162(51 \%)\end{array}$ & $\begin{array}{l}\text { Not } \\
\text { reported }\end{array}$ & Not reported \\
\hline $\begin{array}{l}\text { Lim et. } \\
\text { al. }{ }^{55}\end{array}$ & $\begin{array}{l}\text { Multicentre } \\
\text { prospective } \\
\text { cohort study } \\
\text { Interim } \\
\text { analysis } \\
\\
\text { United } \\
\text { Kingdom }\end{array}$ & Lymphoma & $\begin{array}{l}129 \text { patients } \\
\text { recruited } \\
119 \\
\text { analysed } \\
-66 \% \\
\text { indolent B- } \\
\mathrm{NHL} \\
-29 \% \\
\text { aggressive } \\
\mathrm{B}-\mathrm{NHL} \\
-10 \% \mathrm{HL} \\
-3 \% \text { other } \\
150 \text { control }\end{array}$ & $\begin{array}{l}69 \text { years } \\
\text { (IQR 57- } \\
74)\end{array}$ & $\begin{array}{l}81 \text { Male } \\
48 \text { Female }\end{array}$ & $\begin{array}{l}\text { BNT162b2 } \\
\text { ChAdOx1 }\end{array}$ & $\begin{array}{l}\text { SARS-CoV-2 } \\
\text { S IgG } \\
\text { Meso Scale } \\
\text { Discovery } \\
>0.55 \\
\text { BAU/ml = } \\
\text { positive } \\
\text { RBD IgG } \\
>0.73 \\
\text { BAU/ml = } \\
\text { positive }\end{array}$ & $\begin{array}{l}14 \text { days post } \\
\text { first dose: } \\
32 / 59 \text { (54\%) } \\
\text { patients } \\
\text { vs. } \\
65 / 65 \text { (100\%) } \\
\text { controls } \\
\text { 14-28 days } \\
\text { post second } \\
\text { dose: } \\
61 / 86 \text { (71\%) } \\
\text { patients } \\
\text { vs. }\end{array}$ & $\begin{array}{l}\text { Not } \\
\text { reported }\end{array}$ & Not reported \\
\hline
\end{tabular}




\begin{tabular}{|c|c|c|c|c|c|c|c|c|c|c|}
\hline & & $\begin{array}{l}\text { Healthy } \\
\text { control }\end{array}$ & & & & & & $\begin{array}{l}85 / 85(100 \%) \\
\text { controls }\end{array}$ & & \\
\hline $\begin{array}{l}\text { Perry et. } \\
\text { al. }^{56}\end{array}$ & $\begin{array}{l}\text { Single centre } \\
\text { prospective } \\
\text { cohort study } \\
\text { Israel }\end{array}$ & $\begin{array}{l}\text { Lymphoma } \\
\text {-B cell NHL } \\
\text { Healthy } \\
\text { control }\end{array}$ & $\begin{array}{l}149 \text { patients } \\
-53 \% \\
\text { indolent } \\
\mathrm{NHL} \\
-47 \% \\
\text { aggressive } \\
\mathrm{NHL} \\
\\
65 \text { controls }\end{array}$ & $\begin{array}{l}64 \text { years } \\
(20-92)\end{array}$ & $\begin{array}{l}88 \text { Male } \\
61 \text { Female }\end{array}$ & BNT162b2 & $\begin{array}{l}\text { SARS-CoV-2 } \\
\text { S IgG } \\
\text { Roche } \\
\geq 0.8 \mathrm{IU} / \mathrm{ml} \\
=\text { positive }\end{array}$ & $\begin{array}{l}\text { 14-21 days } \\
\text { post second } \\
\text { dose: } \\
73 / 149 \text { (49\%) } \\
\text { vs. } \\
64 / 65 \text { (99\%) } \\
\text { controls } \\
38 / 80 \text { (48\%) } \\
\text { indolent NHL } \\
34 / 69(49 \%) \\
\text { aggressive } \\
\mathrm{NHL}\end{array}$ & $\begin{array}{l}\text { Not } \\
\text { reported }\end{array}$ & $\begin{array}{l}\text { At least } 1 \\
\text { adverse } \\
\text { event: } \\
60 / 118 \text { (51\%) } \\
44 / 118(37 \%) \\
\text { local AE } \\
\text { 23/118 (20\%) } \\
\text { Systemic AE }\end{array}$ \\
\hline \multicolumn{11}{|c|}{ HCT specific studies } \\
\hline $\begin{array}{l}\text { Easdale et. } \\
\text { al. } 57\end{array}$ & $\begin{array}{l}\text { Single centre } \\
\text { retrospective } \\
\text { cohort study } \\
\text { United } \\
\text { Kingdom }\end{array}$ & $\begin{array}{l}\text { Allogeneic } \\
\mathrm{HCT} \\
>3 \text { months }\end{array}$ & 55 patients & $\begin{array}{l}50 \text { years } \\
(18-73)\end{array}$ & $\begin{array}{l}34 \text { Male } \\
21 \text { Female }\end{array}$ & $\begin{array}{l}\text { BNT162b2 } \\
\text { ChAdOx1 } \\
38 \% \\
62 \%\end{array}$ & $\begin{array}{l}\text { SARS-CoV-2 } \\
\text { S IgG } \\
\text { Ortho } \\
\text { clinical } \\
\geq 1 \\
\text { signal/cut- } \\
\text { off = } \\
\text { positive }\end{array}$ & $\begin{array}{l}42 \text { days post } \\
\text { first dose: } \\
21 / 55(38 \%)\end{array}$ & $\begin{array}{l}\text { Not } \\
\text { reported }\end{array}$ & Not reported \\
\hline $\begin{array}{l}\text { Redjoul et. } \\
\text { al. }{ }^{58}\end{array}$ & $\begin{array}{l}\text { Single centre } \\
\text { retrospective } \\
\text { cohort study } \\
\text { France }\end{array}$ & $\begin{array}{l}\text { Allogeneic } \\
\text { HCT }\end{array}$ & 88 patients & $\begin{array}{l}\text { Not } \\
\text { reported }\end{array}$ & $\begin{array}{l}47 \text { Male } \\
41 \text { Female }\end{array}$ & BNT162b2 & $\begin{array}{l}\text { SARS-CoV-2 } \\
\text { S IgG } \\
\text { Abbott } \\
>21 \mathrm{AU} / \mathrm{ml} \\
=\text { positive } \\
>4160 \\
\mathrm{AU} / \mathrm{ml}=\end{array}$ & $\begin{array}{l}28 \text { days post } \\
\text { second dose: } \\
69 / 88(78 \%) \\
>4160 \mathrm{AU} / \mathrm{ml} \\
28 \text { days post } \\
\text { second dose: }\end{array}$ & $\begin{array}{l}\text { Not } \\
\text { reported }\end{array}$ & Not reported \\
\hline
\end{tabular}




\begin{tabular}{|c|c|c|c|c|c|c|c|c|c|c|}
\hline & & & & & & & $\begin{array}{l}\text { neutralisati } \\
\text { on }\end{array}$ & $52 / 88(59 \%)$ & & \\
\hline $\begin{array}{l}\text { Ram et. } \\
\text { al. }^{59}\end{array}$ & $\begin{array}{l}\text { Single centre } \\
\text { prospective } \\
\text { cohort study } \\
\text { Israel }\end{array}$ & $\begin{array}{l}\text { Allogeneic } \\
\text { HCT and } \\
\text { CAR-T } \\
>3 \text { months }\end{array}$ & $\begin{array}{l}80 \text { patients } \\
-83 \% \\
\text { alloHCT } \\
-17 \% \text { CAR-T }\end{array}$ & $\begin{array}{l}65 \text { years } \\
(23-83)\end{array}$ & $\begin{array}{l}44 \text { Male } \\
37 \text { Female }\end{array}$ & BNT162b2 & $\begin{array}{l}\text { SARS-CoV-2 } \\
\text { S IgG } \\
\text { Roche } \\
\geq 0.8 \mathrm{U} / \mathrm{ml} \\
=\text { positive } \\
\text { SARS-CoV-2 } \\
\text { specific } \\
\text { cells } \\
\text { ELISPOT, } \\
\text { (IFN, IL2) } \\
4 \\
\text { spots/well } \\
=\text { positive }\end{array}$ & $\begin{array}{l}7 \text { to } 14 \text { days } \\
\text { post second } \\
\text { dose: } \\
47 / 63(75 \%) \\
\text { alloHCT } \\
5 / 14(36 \%) \\
\text { CAR-T }\end{array}$ & $\begin{array}{l}\text { Cellular } \\
7 \text { to } 14 \text { days } \\
\text { post second } \\
\text { dose: } \\
7 / 37(19 \%) \\
\text { alloHCT } \\
6 / 12(50 \%) \\
\text { CAR-T }\end{array}$ & $\begin{array}{l}\text { At least } 1 \\
\text { adverse } \\
\text { event: } \\
\text { First dose } \\
\text { 11/80 (14\%) } \\
\text { 3/80 (4\%) } \\
\text { GvHD } \\
\text { Second dose } \\
\text { 18/74 (24\%) } \\
\text { 3/74 (4\%) } \\
\text { GvHD }\end{array}$ \\
\hline $\begin{array}{l}\text { Dhakal et. } \\
\text { al. }{ }^{60}\end{array}$ & $\begin{array}{l}\text { Single centre } \\
\text { retrospective } \\
\text { cohort study } \\
\text { United States }\end{array}$ & $\begin{array}{l}\text { Autologous } \\
\text { Allogeneic } \\
\text { HCT } \\
\text { CAR-T }\end{array}$ & $\begin{array}{l}130 \text { patients } \\
-45 \text { autoHCT } \\
-71 \text { alloHCT } \\
-14 \text { CAR-T }\end{array}$ & $\begin{array}{l}\text { AutoHCT } \\
65 \text { years } \\
(45-75) \\
\text { AlloHCT } \\
64 \text { years } \\
(25-77) \\
\text { CAR-T } \\
\text { Not } \\
\text { reported }\end{array}$ & $\begin{array}{l}\text { Not } \\
\text { reported }\end{array}$ & $\begin{array}{l}\text { BNT162b2 } \\
\text { mRNA-1273 } \\
\text { Ad26 } \\
59 \% \\
36 \% \\
5 \%\end{array}$ & $\begin{array}{l}\text { SARS-CoV-2 } \\
\text { S IgG } \\
\text { EUROIMM } \\
\text { UN } \\
\geq 1.1 \\
\text { signal/cut- } \\
\text { off = } \\
\text { positive }\end{array}$ & $\begin{array}{l}14 \text { days post } \\
\text { completion of } \\
\text { vaccination: } \\
27 / 45(60 \%) \\
\text { autoHCT } \\
49 / 71(38 \%) \\
\text { alloHCT } \\
3 / 14(21 \%) \\
\text { CAR-T }\end{array}$ & $\begin{array}{l}\text { Not } \\
\text { reported }\end{array}$ & Not reported \\
\hline \multicolumn{11}{|c|}{ Myeloproliferative neoplasms and chronic myeloid leukaemia specific studies } \\
\hline $\begin{array}{l}\text { Caocci et. } \\
\text { al. }{ }^{61}\end{array}$ & $\begin{array}{l}\text { Single centre } \\
\text { prospective } \\
\text { cohort study } \\
\text { Italy }\end{array}$ & MPN & $\begin{array}{l}20 \text { patients } \\
-65 \% \text { MF } \\
-30 \% \text { ET } \\
-5 \% \text { PV }\end{array}$ & $\begin{array}{l}66 \text { years } \\
(48-82)\end{array}$ & $\begin{array}{l}\text { Not } \\
\text { reported }\end{array}$ & BNT162b2 & $\begin{array}{l}\text { SARS-CoV-2 } \\
\text { S IgG } \\
\text { DiaSorin } \\
\geq 15 \mathrm{AU} / \mathrm{ml} \\
=\text { positive }\end{array}$ & $\begin{array}{l}42 \text { days post } \\
\text { second dose: } \\
13 / 20(65 \%)\end{array}$ & $\begin{array}{l}\text { Not } \\
\text { reported }\end{array}$ & Not reported \\
\hline
\end{tabular}




\begin{tabular}{|c|c|c|c|c|c|c|c|c|c|c|}
\hline $\begin{array}{l}\text { Chowdhur } \\
\text { y et. al. }{ }^{62}\end{array}$ & $\begin{array}{l}\text { Single centre } \\
\text { retrospective } \\
\text { cohort } \\
\text { United } \\
\text { Kingdom }\end{array}$ & $\begin{array}{l}\text { CML and MPN } \\
\text { Healthcare } \\
\text { workers } \\
>60 \text { years old }\end{array}$ & $\begin{array}{l}59 \text { patients } \\
232 \text { controls }\end{array}$ & $\begin{array}{l}62 \text { years } \\
\text { (IQR 52- } \\
73)\end{array}$ & $\begin{array}{l}27 \text { Male } \\
32 \text { Female }\end{array}$ & $\begin{array}{l}\text { BNT162b2 } \\
\text { ChAdOx1 } \\
37 \% \\
63 \%\end{array}$ & $\begin{array}{l}\text { SARS-CoV-2 } \\
\text { S IgG } \\
\text { Abbott } \\
\geq 50 \\
\text { AU/mL = } \\
\text { positive }\end{array}$ & $\begin{array}{l}\geq 2 \text { weeks } \\
\text { post first } \\
\text { dose: } \\
34 / 59(57 \%) \\
224 / 232 \\
(97 \%)\end{array}$ & $\begin{array}{l}\text { Not } \\
\text { reported }\end{array}$ & Not reported \\
\hline $\begin{array}{l}\text { Guglielmel } \\
\text { li et. al. }{ }^{63}\end{array}$ & $\begin{array}{l}\text { Single centre } \\
\text { prospective } \\
\text { cohort study } \\
\text { Italy }\end{array}$ & $\begin{array}{l}\text { MPN } \\
\text { Healthy } \\
\text { controls }\end{array}$ & $\begin{array}{l}30 \text { patients } \\
-43 \% \mathrm{MF} \\
-33 \% \mathrm{PV} \\
-23 \% \mathrm{ET} \\
14 \text { controls }\end{array}$ & $\begin{array}{l}\text { Not } \\
\text { reported } \\
\text { overall }\end{array}$ & $\begin{array}{l}10 \text { Male } \\
20 \text { Female }\end{array}$ & $\begin{array}{l}\text { BNT162b2 } \\
\text { mRNA-1273 } \\
83 \% \\
17 \%\end{array}$ & $\begin{array}{l}\text { SARS-CoV-2 } \\
\text { S/RBD IgG } \\
\text { Not } \\
\text { specified }\end{array}$ & $\begin{array}{l}21 \text { to } 28 \text { days } \\
\text { post first } \\
\text { dose: } \\
18 / 30(60 \%) \\
\text { vs. } \\
14 / 14(100 \%) \\
\text { controls }\end{array}$ & $\begin{array}{l}21 \text { to } 28 \\
\text { days post } \\
\text { first dose: } \\
13 / 30(43 \%) \\
\text { vs. } \\
14 / 14 \\
(100 \%) \\
\text { controls }\end{array}$ & Not reported \\
\hline $\begin{array}{l}\text { Harrington } \\
\text { et. al. }{ }^{64}\end{array}$ & $\begin{array}{l}\text { Single centre } \\
\text { prospective } \\
\text { cohort study } \\
\text { United } \\
\text { Kingdom }\end{array}$ & CML & $\begin{array}{l}16 \text { patients } \\
-C M L\end{array}$ & $\begin{array}{l}45 \text { years } \\
(23-74)\end{array}$ & $\begin{array}{l}12 \text { Male } \\
4 \text { Female }\end{array}$ & BNT162b2 & $\begin{array}{l}\text { SARS-CoV-2 } \\
\text { S IgG 'in } \\
\text { house' } \\
\text { 1:25 = } \\
\text { positive } \\
\text { SARS-CoV-2 } \\
\text { neutralising } \\
\text { 'in house' } \\
\text { ID50 = } \\
\text { positive } \\
\text { SARS-CoV-2 } \\
\text { T cells } \\
\text { ICS (IFN, } \\
\text { IL2) } \\
3 \text { fold } \\
\text { increase = } \\
\text { positive }\end{array}$ & $\begin{array}{l}21 \text { days post } \\
\text { first dose: } \\
14 / 16(88 \%)\end{array}$ & $\begin{array}{l}\text { Neutralising } \\
\text { antibody } \\
21 \text { days post } \\
\text { first dose: } \\
6 / 16(38 \%) \\
\text { Cellular: } \\
\text { 14/15 (80\%) }\end{array}$ & $\begin{array}{l}\text { Local adverse } \\
\text { events: } 8 / 16 \\
(50 \%) \\
\text { Systemic } \\
\text { adverse } \\
\text { events: } 9 / 16 \\
\text { (56\%) }\end{array}$ \\
\hline
\end{tabular}




\begin{tabular}{|c|c|c|c|c|c|c|c|c|c|c|}
\hline $\begin{array}{l}\text { Harrington } \\
\text { et. al. }{ }^{65}\end{array}$ & $\begin{array}{l}\text { Single centre } \\
\text { prospective } \\
\text { cohort study } \\
\text { United } \\
\text { Kingdom }\end{array}$ & MPN & 21 patients & $\begin{array}{l}58 \text { years } \\
(36-72)\end{array}$ & $\begin{array}{l}7 \text { Male } \\
21 \text { Female }\end{array}$ & BNT162b2 & $\begin{array}{l}\text { SARS-CoV-2 } \\
\text { S IgG 'in } \\
\text { house' } \\
1: 25= \\
\text { positive } \\
\text { SARS-CoV-2 } \\
\text { neutralising } \\
\text { 'in house' } \\
\text { ID50 = } \\
\text { positive } \\
\text { SARS-CoV-2 } \\
\text { T cells } \\
\text { ICS (IFN, } \\
\text { IL2) } \\
3 \text { fold } \\
\text { increase = } \\
\text { positive }\end{array}$ & $\begin{array}{l}21 \text { days post } \\
\text { first dose: } \\
16 / 21(76 \%)\end{array}$ & $\begin{array}{l}\text { Neutralising } \\
\text { antibody } \\
21 \text { days post } \\
\text { first dose: } \\
\text { 18/21 (86\%) } \\
\text { Cellular } \\
\text { (CD4): } \\
15 / 20(75 \%)\end{array}$ & $\begin{array}{l}\text { At least } 1 \\
\text { adverse } \\
\text { event: } \\
\text { 12/21 (57\%) } \\
\text { local } \\
\text { 10/21 (48\%) } \\
\text { systemic }\end{array}$ \\
\hline $\begin{array}{l}\text { Pimpinelli } \\
\text { et. al. }^{66}\end{array}$ & $\begin{array}{l}\text { Single centre } \\
\text { prospective } \\
\text { cohort study } \\
\text { Italy }\end{array}$ & MPN & $\begin{array}{l}42 \text { patients } \\
-40 \% \text { ET } \\
-36 \% \text { PV } \\
-24 \% \mathrm{MF}\end{array}$ & $\begin{array}{l}72 \text { years } \\
(52-82)\end{array}$ & $\begin{array}{l}20 \text { Male } \\
22 \text { Female }\end{array}$ & BNT162b2 & $\begin{array}{l}\text { SARS-CoV-2 } \\
\text { S IgG } \\
\text { DiaSorin } \\
\geq 15 \mathrm{AU} / \mathrm{ml} \\
=\text { positive }\end{array}$ & $\begin{array}{l}21 \text { days post } \\
\text { first dose: } \\
23 / 42(55 \%) \\
14 \text { days post } \\
\text { second dose: } \\
36 / 42 \text { ( } 86 \%)\end{array}$ & $\begin{array}{l}\text { Not } \\
\text { reported }\end{array}$ & Not reported \\
\hline
\end{tabular}

*Excluded from meta-analysis

Haem: haematology; CLL: chronic lymphocytic leukaemia; NHL: non hodgkins lymphoma; HL: hodgkins lymphoma; AML: acute myeloid leukaemia; MDS: myelodysplastic syndrome; MM: myeloma; MGUS: monoclonal gammopathy of unknown significance; WG: Waldenstrom's magroglobulinaemia; HCT: haematopoietic stem cell transplantation; CAR-T: chimeric antigen receptor T cell; MPN: myeloproliferative neoplasm; CML: chronic myeloid leukaemia; ET: Essential thrombocytosis; PV: polycythaemia vera; MF: myelofibrosis; AU: arbitrary unit

BNT162b2: Tozinameran (Pfizer); mRNA1273: Spikevax (Moderna); ChAdOx1: Vaxzevria (AstraZeneca); Ad26: Janssen

Table 1: Summary of study characteristics and outcomes for patients with haematological malignancy by overall cohort and by specific underlying disease 


\begin{tabular}{|c|c|c|c|c|}
\hline & $\begin{array}{l}\text { Single arm studies } \\
\text { Pooled response rate } \\
(95 \% \mathrm{Cl})\end{array}$ & $\begin{array}{l}\text { Malignancy arm of } \\
\text { comparator studies } \\
\text { Pooled response rate } \\
(95 \% \mathrm{Cl})\end{array}$ & $\begin{array}{l}\text { Control arm of comparator } \\
\text { studies } \\
\text { Pooled response rate } \\
(95 \% \mathrm{Cl})\end{array}$ & $\begin{array}{l}\text { Intervention vs. control } \\
\text { cohort } \\
\text { Odds ratio }(95 \% \mathrm{Cl}) \\
\text { Heterogeneity } \\
p \text {-value }\end{array}$ \\
\hline \multicolumn{5}{|c|}{ Overall: Patients with haematological malignancy } \\
\hline $\begin{array}{l}\text { Following second dose } \\
4733 \text { patients }\end{array}$ & $\begin{array}{l}0.61(0.54-0.69) \\
I^{2}=92 \%, p<0.01\end{array}$ & $\begin{array}{l}0.67(0.58-0.76) \\
I^{2}=93 \%, p<0.01\end{array}$ & $\begin{array}{l}0.96(0.91-1.00) \\
I^{2}=84 \%, p<0.01\end{array}$ & $\begin{array}{l}\text { OR } 0.05(0.02-0.15) \\
p<0.01 \\
I^{2}=88 \%, p<0.01\end{array}$ \\
\hline $\begin{array}{l}\text { Following first dose } \\
2331 \text { patients }\end{array}$ & $\begin{array}{l}0.51(0.38-0.64) \\
I^{2}=92 \%, p<0.01\end{array}$ & $\begin{array}{l}0.37(0.23-0.51) \\
I^{2}=90 \%, p<0.01\end{array}$ & $\begin{array}{l}0.78(0.62-0.95) \\
I^{2}=98 \%, p<0.01\end{array}$ & $\begin{array}{l}\text { OR } 0.10(0.04-0.29) \\
p<0.01 \\
I^{2}=86 \%, p<0.01\end{array}$ \\
\hline \multicolumn{5}{|l|}{ Myeloma } \\
\hline $\begin{array}{l}\text { Following second dose } \\
1218 \text { patients }\end{array}$ & $\begin{array}{l}0.80(0.64-0.95) \\
I^{2}=85 \%, p<0.01\end{array}$ & $\begin{array}{l}0.76(0.70-0.82) \\
1^{2}=90 \%, p<0.01\end{array}$ & $\begin{array}{l}0.98(0.95-1.00) \\
I^{2}=71 \%, p<0.01\end{array}$ & $\begin{array}{l}\text { OR } 0.09(0.03-0.29) \\
P<0.01 \\
I^{2}=49 \%, p=0.08\end{array}$ \\
\hline $\begin{array}{l}\text { Following first dose } \\
685 \text { patients }\end{array}$ & $\begin{array}{l}0.43(0.18-0.68) \\
I^{2}=91 \%, p<0.01\end{array}$ & $\begin{array}{l}0.29(0.09-0.48) \\
I^{2}=81 \%, p<0.01\end{array}$ & $\begin{array}{l}0.64(0.42-0.87) \\
I^{2}=76 \%, p<0.01\end{array}$ & $\begin{array}{l}\text { OR } 0.23(0.05-0.99) \\
p=0.05 \\
I^{2}=49 \%, p=0.11\end{array}$ \\
\hline \multicolumn{5}{|c|}{ Chronic lymphocytic leukaemia } \\
\hline Following second dose & $0.51(0.37-0.65)$ & $0.51(0.34-0.68)$ & $1.00(0.99-1.00)$ & $\begin{array}{l}\text { OR } 0.01(0.01-0.03) \\
p<0.01\end{array}$ \\
\hline
\end{tabular}




\begin{tabular}{|c|c|c|c|c|}
\hline 1446 patients & $1^{2}=91 \%, p<0.01$ & $1^{2}=56 \%, p=0.06$ & $I^{2}=0 \%, p=0.07$ & $I^{2}=0 \%, p=0.9$ \\
\hline $\begin{array}{l}\text { Following first dose } \\
111 \text { patients }\end{array}$ & Single study & $\begin{array}{l}0.18(0.00-1.00) \\
I^{2}=89 \%, p<0.01\end{array}$ & $\begin{array}{l}0.92(0.52-1.00) \\
I^{2}=0 \%, p=0.32\end{array}$ & $\begin{array}{l}\text { OR } 0.03(0.00-0.80) \\
p=0.05 \\
I^{2}=0 \%, p=0.60\end{array}$ \\
\hline \multicolumn{5}{|l|}{ Lymphoma } \\
\hline $\begin{array}{l}\text { Following second dose } \\
1227 \text { patients }\end{array}$ & $\begin{array}{l}0.52(0.28-0.75) \\
I^{2}=97 \%, p<0.01\end{array}$ & $\begin{array}{l}0.55(0.35-0.76) \\
I^{2}=84 \%, p<0.01\end{array}$ & $\begin{array}{l}0.99(0.98-1.00) \\
I^{2}=0 \%, p=0.72\end{array}$ & $\begin{array}{l}\text { OR } 0.02(0.01-0.02) \\
p<0.01 \\
I^{2}=0 \%, p=1.0\end{array}$ \\
\hline $\begin{array}{l}\text { Following first dose } \\
69 \text { patients }\end{array}$ & No studies available & $\begin{array}{l}0.33(0.00-1.00) \\
I^{2}=93 \%, p<0.01\end{array}$ & $\begin{array}{l}0.95(0.09-1.00) \\
I^{2}=71 \%, p=0.06\end{array}$ & $\begin{array}{l}\text { OR } 0.01(0.0-1.24) \\
p=0.05 \\
I^{2}=0 \%, p=0.7\end{array}$ \\
\hline \multicolumn{5}{|c|}{ Haematopoietic stem cell transplant and cellular therapies } \\
\hline $\begin{array}{l}\text { Following second dose } \\
401 \text { patients }\end{array}$ & $\begin{array}{l}0.61(0.42-0.80) \\
1^{2}=88 \%, p=0.05\end{array}$ & Single study & Single study & Single study \\
\hline $\begin{array}{l}\text { Following first dose } \\
21 \text { patients }\end{array}$ & Single study & No studies available & No studies available & No studies available \\
\hline \multicolumn{5}{|c|}{ Acute leukaemia and Myelodysplastic syndrome } \\
\hline $\begin{array}{l}\text { Following second dose } \\
113 \text { patients }\end{array}$ & $\begin{array}{l}0.93(0.80-1.00) \\
I^{2}=29 \%, p=0.24\end{array}$ & Single study & Single study & Single study \\
\hline
\end{tabular}




\begin{tabular}{|c|c|c|c|c|}
\hline $\begin{array}{l}\text { Following first dose } \\
13 \text { patients }\end{array}$ & Single study & Single study & Single study & Single study \\
\hline \multicolumn{5}{|c|}{ Myeloproliferative neoplasm and chronic myeloid leukaemia } \\
\hline $\begin{array}{l}\text { Following second dose } \\
281 \text { patients }\end{array}$ & $\begin{array}{l}0.88(0.72-1.00) \\
I^{2}=70 \%, p=0.01\end{array}$ & $\begin{array}{l}0.87(0.81-0.92) \\
\mathrm{I}^{2}=0 \%, p=0.83\end{array}$ & $\begin{array}{l}0.99(0.98-1.00) \\
I^{2}=0 \%, p=0.90\end{array}$ & $\begin{array}{l}\text { OR } 0.07(0.0-1.55) \\
p=0.06 \\
\mathrm{I}^{2}=0 \%, p=0.77\end{array}$ \\
\hline $\begin{array}{l}\text { Following first dose } \\
222 \text { patients }\end{array}$ & $\begin{array}{l}0.71(0.30-1.00) \\
I^{2}=76 \%, p=0.01\end{array}$ & $\begin{array}{l}0.54(0.37-0.71) \\
I^{2}=0 \%, p=0.46\end{array}$ & $\begin{array}{l}0.85(0.51-1.00) \\
I^{2}=90 \%, p<0.01\end{array}$ & $\begin{array}{l}\text { OR } 0.13(0.01-1.71) \\
p=0.09 \\
I^{2}=88 \%, p<0.01\end{array}$ \\
\hline
\end{tabular}

Table 2: Summary of pooled seropositivity rates for patients with haematological malignancy and by underlying disease type and number of vaccine doses 


\begin{tabular}{|c|c|c|c|}
\hline & $\begin{array}{l}\text { Positive neutralising } \\
\text { antibody response } \\
\text { Pooled response } \\
\text { rate }(95 \% \mathrm{Cl})\end{array}$ & $\begin{array}{l}\text { Positive cellular } \\
\text { response } \\
\text { Pooled response } \\
\text { rate }(95 \% \mathrm{Cl})\end{array}$ & $\begin{array}{l}\text { At least } 1 \text { adverse } \\
\text { event rate } \\
\text { Pooled response } \\
\text { rate }(95 \% \mathrm{Cl})\end{array}$ \\
\hline \multicolumn{4}{|c|}{ Overall: Patients with haematological malignancy } \\
\hline $\begin{array}{l}\text { Following second } \\
\text { dose }\end{array}$ & $\begin{array}{l}\text { Malignancy arm of } \\
\text { comparator studies: } \\
0.57 \text { (Single study) }\end{array}$ & $\begin{array}{l}\text { Single arm: } \\
0.40(0.00-1.00) \\
\text { Malignancy arm of } \\
\text { comparator studies: } \\
0.75 \text { (single study) }\end{array}$ & $\begin{array}{l}0.36(0.24-0.48) \\
I^{2}=97 \%, p<0.01\end{array}$ \\
\hline Following first dose & $\begin{array}{l}\text { Single arm: } \\
0.63(0.00-1.00) \\
\text { Malignancy arm of } \\
\text { comparator studies: } \\
0.18(0.00-0.44)\end{array}$ & $\begin{array}{l}\text { Single arm: } \\
0.86(0.00-1.00) \\
\text { Malignancy arm of } \\
\text { comparator studies: } \\
0.33 \text { (single study) }\end{array}$ & $\begin{array}{l}0.39(0.18-0.60) \\
I^{2}=97 \%, p<0.01\end{array}$ \\
\hline
\end{tabular}

Table 3: Summary of pooled rates of positive neutralising antibody, cellular responses and adverse events 


\begin{tabular}{|c|c|c|c|}
\hline & $\begin{array}{l}\text { Intervention arm } \\
\text { Pooled response rate }(95 \% \mathrm{Cl}) \\
\text { Heterogeneity } \\
p \text {-value }\end{array}$ & $\begin{array}{l}\text { Control arm } \\
\text { Pooled response rate }(95 \% \mathrm{Cl}) \\
\text { Heterogeneity } \\
p \text {-value }\end{array}$ & $\begin{array}{l}\text { Intervention vs. control cohort } \\
\text { Odds ratio }(95 \% \mathrm{Cl}) \\
\text { Heterogeneity } \\
p \text {-value }\end{array}$ \\
\hline \multicolumn{4}{|c|}{ Active therapy vs. no active therapy } \\
\hline Following second dose & $\begin{array}{l}0.28(0.08-0.48) \\
I^{2}=83 \%, p<0.01\end{array}$ & $\begin{array}{l}0.62(0.39-0.86) \\
1^{2}=94 \%, p<0.01\end{array}$ & $\begin{array}{l}\text { OR } 0.21(0.06-0.67) \\
p=0.02 \\
I^{2}=75 \%, p<0.01\end{array}$ \\
\hline Following first dose & $\begin{array}{l}0.42(0.09-0.75) \\
I^{2}=49 \%, p=0.08\end{array}$ & $\begin{array}{l}0.81(0.66-0.95) \\
I^{2}=0 \%, p=0.62\end{array}$ & $\begin{array}{l}\text { OR } 0.19(0.03-1.19) \\
p=0.06 \\
I^{2}=24 \%, p=0.27\end{array}$ \\
\hline \multicolumn{4}{|c|}{ CD-20 antibody therapy within 12 months vs. CD-20 therapy 12 or more months } \\
\hline Following second dose & $\begin{array}{l}0.19(0.00-0.50) \\
I^{2}=88 \%, p<0.01\end{array}$ & $\begin{array}{l}0.61(0.41-0.82) \\
I^{2}=88 \%, p<0.01\end{array}$ & $\begin{array}{l}\text { OR } 0.08(0.01-0.59) \\
p=0.02 \\
I^{2}=57 \%, p=0.04\end{array}$ \\
\hline Following first dose & Single study & Single study & Single study \\
\hline \multicolumn{4}{|l|}{ Targeted therapy } \\
\hline Following second dose & $\begin{array}{l}0.35(0.19-0.52) \\
\left.\right|^{2}=94 \%, p<0.01\end{array}$ & No control & No analysis \\
\hline Following first dose & Single study & No control & No analysis \\
\hline
\end{tabular}




\begin{tabular}{|l|l|l|l|}
\hline Haematopoietic stem cell transplant or cellular therapy within 12 months vs. 12 or more \\
\hline Following second dose & $\begin{array}{l}0.66(0.43-0.88) \\
\mathrm{I}^{2}=0 \%, p=0.63\end{array}$ & $\begin{array}{l}0.68(0.40-0.95) \\
\mathrm{I}^{2}=45 \%, p=0.16\end{array}$ & $\begin{array}{l}\text { OR } 0.96(0.11-8.74) \\
p=0.94 \\
\mathrm{I}^{2}=36 \%, p=0.21\end{array}$ \\
\hline Following first dose & Single study & Single study & Single study \\
\hline Vaccine type BNT162b2 vs. non-BNT162b2 & $0.95(0.39-1.00)$ & $0.91(0.62-1.00)$ & $\begin{array}{l}\text { OR } 1.93(0.00->1) \\
p=0.69 \\
I^{2}=71 \%, p=0.06\end{array}$ \\
\hline Following second dose & $\mathrm{I}^{2}=66 \%, p=0.09$ & $\begin{array}{l}\text { OR } 0.80(0.42-1.51) \\
p=0.26\end{array}$ \\
\hline Following first dose & $0.62(0.29-0.95)$ & $0.68(0.24-1.00)$ & $\begin{array}{l}\mathrm{I}^{2}=0 \%, p=0.82 \\
\mathrm{I}^{2}=0.44\end{array}$ \\
\hline
\end{tabular}

Table 4: Summary of subgroup analysis by active treatment, timing of CD20 antibody therapy, haematopoietic stem cell transplantation, receipt of targeted therapies and type of COVID-19 vaccine 
medRxiv preprint doi: https://doi.org/10.1101/2021.11.06.21265967; this version posted November 8, 2021. The copyright holder for this preprint (which was not certified by peer review) is the author/funder, who has granted medRxiv a license to display the preprint in All rights reserved. No reuse allowed without permission.

\section{Figure legend}

Figure 1: Flow diagram of studies identified, screened and included.

\section{Figure 2:}

(A) Odds ratio for achieving seropositivity in patients with haematological malignancy versus healthy control group following two doses of COVID-19 vaccine

(B) Odds ratio of achieving seropositivity in patients with haematological malignancy versus healthy control group following one dose of COVID-19 vaccine

Figure 3:

(A) Pooled rates of seropositivity in single arm studies involving patients with haematological malignancy following two doses of COVID-19 vaccine

(B) Pooled rates of seropositivity in single arm studies involving patients with haematological malignancy following one dose of COVID-19 vaccine 

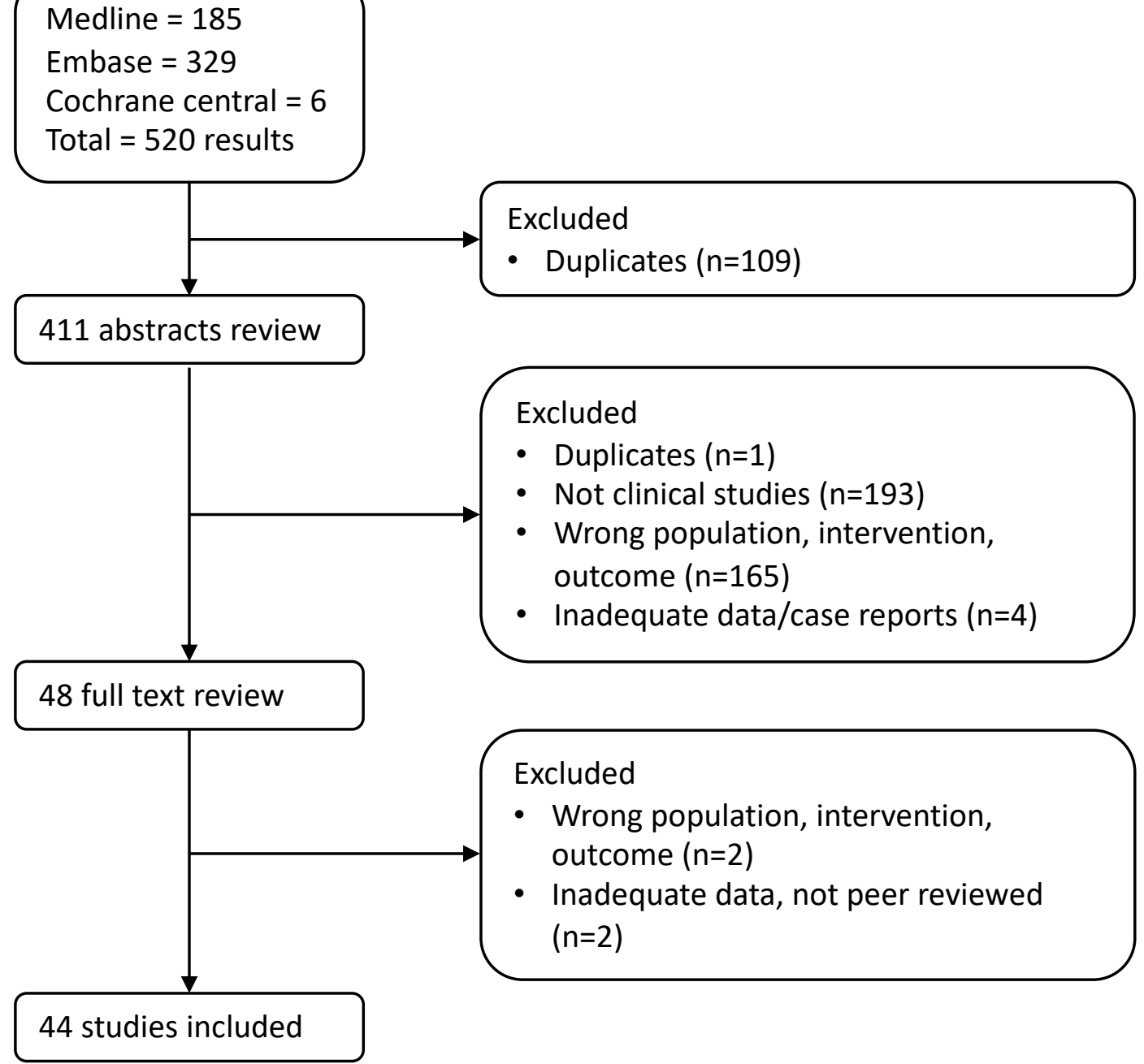

Figure 1: Flow diagram of studies identified, screened and included 
Experimental Control Events Total Events Total

OR $\quad 95 \%-C l$ Weight

$\mathrm{ID}=9$

Herzog Tzarfati, 2021

Random effects model

$235 \quad 315$

Prediction interval

eterogeneity: not applicable

ID = 11

Jurgens, 2021

Random effects mode

Prediction interval

Heterogene

ID $=15$

Monin, 2021

Random effects model

Prediction interval

ID $=18$

Pimpinelli, 2021

Random effects model

Prediction interval

eterogeneity: not applicable

ID $=21$

Avivi, 2021

Random effects model

Prediction interval

Heterogeneity: not applicabs

ID $=26$

Stampfer, 2021

Random effects model

Prediction interval

ID $=29$

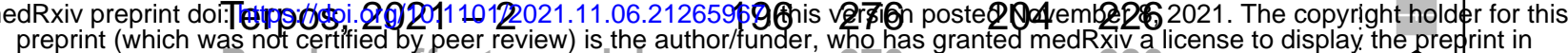

Prediction ill rights reserved. No reuse allowed without permission.

$\mathrm{D}=30$

van Oekelen, 2021

Random effects model

Random effects model
Prediction interval

ID = 34

Herishanu, 2021

Random effects model

Prediction interval

Heterogeneity: not applicable

ID $=36$

Parry, 2021

Random effects model

Prediction interval

Heterogeneity: not applicable

ID $=39$

Ghione, 2021

Random effects model

Prediction interval

Heterogeneity: not applicable

ID $=42$

Lim, 2021

Random effects mode

Prediction interval

ID $=43$

Perry, 2021

Random effects model

Prediction interval

Heterogeneity: not applicable

ID $=45$

Redjoul, 2021

Random effects model

Prediction interval

ren

Random effects model Prediction interval

Heterogeneity: $I^{2}=88 \%, \tau^{2}=1.8053, p<0.0$

Test for overall effect: $t_{13}=-6.29(p<0.01)$

Test for subgroup differences: $x_{13}^{2}=108.78, \mathrm{df}=13(p<0.01)$
$0.03[0.00 ; 0.20] \quad 7.7 \%$

$0.03[0.00 ; 0.20] \quad 7.7 \%$

$0.02[0.00 ; 0.38] \quad 5.6 \%$

$0.02[0.00 ; 0.38] \quad 5.6 \%$

$0.06[0.00 ; 1.46] \quad 4.8 \%$ $0.06[0.00 ; 1.46] \quad 4.8 \%$

$0.07[0.00 ; 1.18] \quad 5.6 \%$

$0.07[0.00 ; 1.18] \quad 5.6 \%$

$0.06[0.01 ; 0.41] \quad 7.6 \%$

$0.06[0.01 ; 0.41] \quad 7.6 \%$

$0.03[0.00 ; 0.53] \quad 5.6 \%$ $0.03[0.00 ; 0.53] \quad 5.6 \%$

$0.26[0.16 ; 0.44] 11.6 \%$ $0.26[0.16 ; 0.44] 11.6 \%$

$-$

$0.04[0.00 ; 0.65] \quad 5.7 \%$ $0.04[0.00 ; 0.65] \quad 5.7 \%$

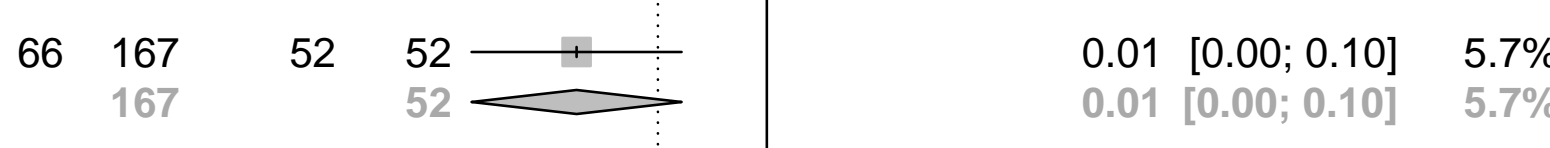

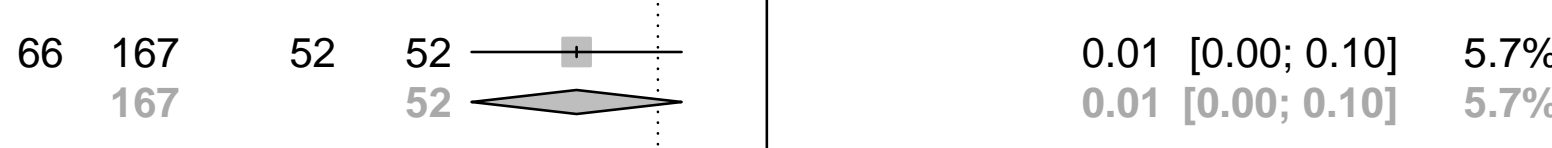

$0.02[0.00 ; 0.48] \quad 5.2 \%$ $0.02[0.00 ; 0.48] \quad 5.2 \%$

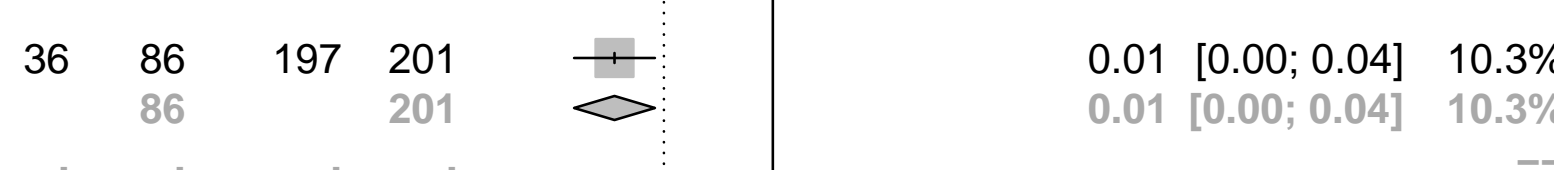

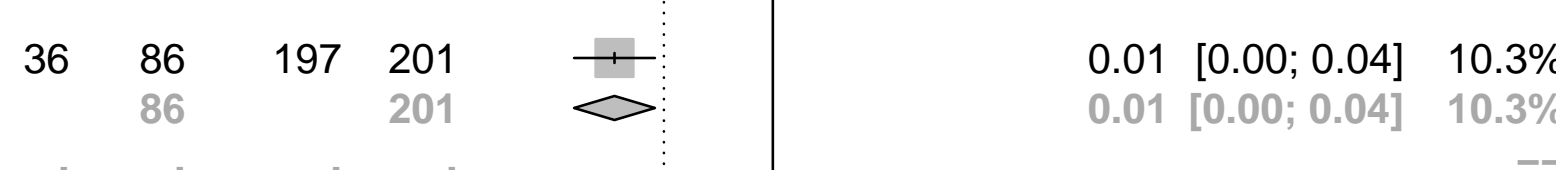

$\begin{array}{lllllll}61 & 86 & 85 & 85 & + & 0.01 \quad[0.00 ; 0.24] & 5.6 \%\end{array}$ $0.01[0.00 ; 0.24] \quad 5.6 \%$

$0.02[0.00 ; 0.11] \quad 7.7 \%$ $0.02[0.00 ; 0.11] \quad 7.7 \%$

$2.51[1.30 ; 4.87] \quad 11.4 \%$ $2.51[1.30 ; 4.87] 11.4 \%$

$0.05[0.02 ; 0.15] 100.0 \%$ $[0.00 ; 1.21]$ 
$\| \mathrm{D}=7$

Gavriatopoulou, 2021

Random effects model

88
58

213
213

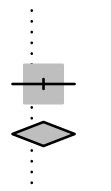

Prediction interval

medRxiv preprint doi: https//doi.org/10 1101/2021.11.06.21265967; this version posted November 8, 2021. The copyright holder for this preprint (which was not certified by peer review) is the author/funder, who has granted medRxiv a license to display the preprint in

ID $=14 \quad$ All rights reserved. No reuse allowed without permission.

Monin, 2021

Random effects model

$\begin{array}{llll}4 & 36 & 18 & 21\end{array}$

Prediction interval

Heterogeneity: not applicable

$\| \mathrm{D}=17$

Pimpinelli, 2021

Random effects model 35

Prediction interval

Heterogeneity: not applicable

ID $=27$

Terpos, 2021 - 1

Random effects model

Prediction interval

Heterogeneity: not applicable

ID $=28$

Terpos, $2021-2$

Random effects model

Prediction interval

Heterogeneity: not applicable

ID $=35$

Parry, 2021

Random effects model

Prediction interval

Heterogeneity: not applicable

II $=41$

Lim, 2021

Random effects model

Prediction interval

Heterogeneity: not applicable

ID $=52$

Chowdhury, 2021

Random effects model

Prediction interval

Heterogeneity: not applicable

ID $=53$

Guglielmelli, 2021

Random effects model

Prediction interval

Heterogeneity: not applicable

Random effects model Prediction interval

$\begin{array}{lll}117 & 276 & 145\end{array}$

$276 \quad 226$

$\begin{array}{llll}12 & 48 & 57 & 102 \\ & 48 & & 102\end{array}$

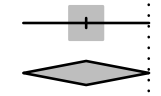

$0.02[0.00 ; 0.10]$

$9.9 \%$

$0.02[0.00 ; 0.10] \quad 9.9 \%$

$0.14[0.06 ; 0.31] \quad 13.0 \%$

$0.14[0.06 ; 0.31] 13.0 \%$

$0.55[0.25 ; 1.20] \quad 13.0 \%$

$0.55[0.25 ; 1.20] \quad 13.0 \%$

$0.26[0.12 ; 0.56] \quad 13.1 \%$

$0.26[0.12 ; 0.56] \quad 13.1 \%$

$0.41 \quad[0.29 ; 0.59] \quad 14.1 \%$

$0.41[0.29 ; 0.59] \quad 14.1 \%$

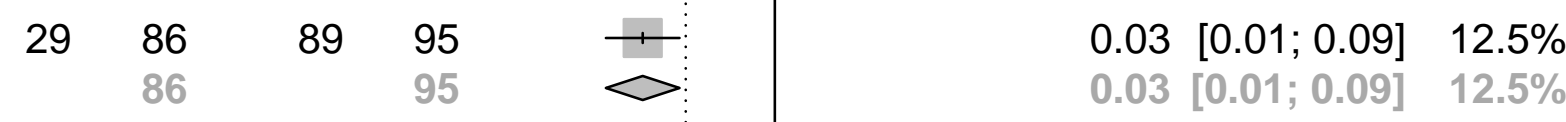

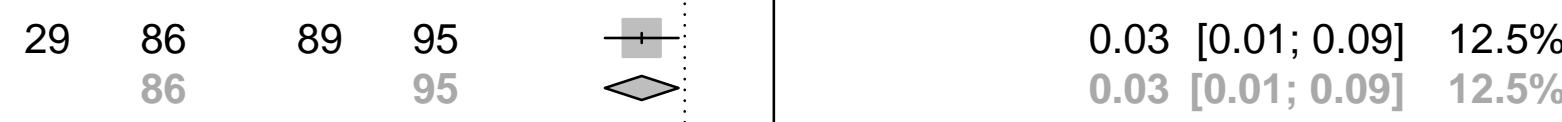

$32 \quad 59 \quad 65$

59

65

$0.01 \quad[0.00 ; 0.15] \quad 6.0 \%$

$0.01[0.00 ; 0.15] \quad 6.0 \%$

$0.05[0.02 ; 0.12] \quad 12.7 \%$

$0.05[0.02 ; 0.12] \quad 12.7 \%$

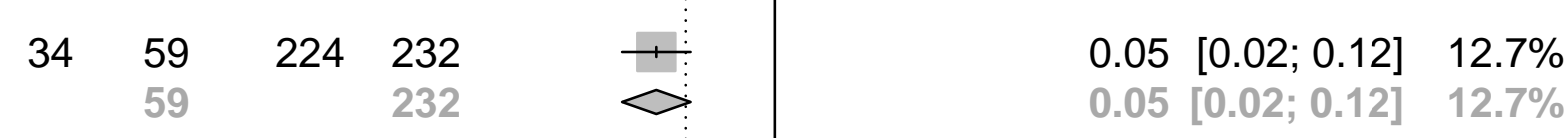

18

30

14

14
14

$0.05[0.00 ; 0.94] \quad 5.8 \%$

$0.05[0.00 ; 0.94] \quad 5.8 \%$

$0.10[0.04 ; 0.29] 100.0 \%$

$[0.00 ; 2.17]$

744

Heterogeneity: $I^{2}=86 \%, \tau^{2}=1.4628, p<0.01$

Test for overall effect: $t_{8}=-5.06(p<0.01)$

Test for subgroup differences: $\chi_{8}^{2}=58.92, \mathrm{df}=8(p<0.01)$

1004

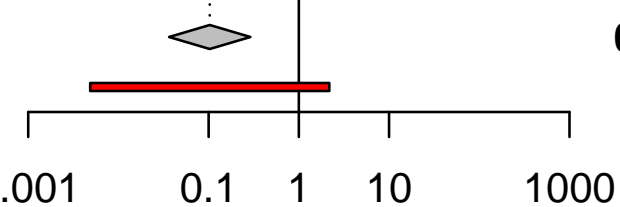

Figure 2B: Odds ratio of achieving seropositivity in patients with haematological malignancy versus healthy control group following one dose of COVID-19 vaccine 
ID $=2$
Addeo, 2021

$\mathrm{D}=3$

Agha, 2021

om effects mode

$36 \quad 67$

$+$

$0.54[0.41 ; 0.66] \quad 5.2 \%$

Prediction interval

$\mathrm{ID}=$

Benda, 2021

Random effects mode

Prediction interval

ID $=6$

Cohen, 2021

Prediction interval

$\mathrm{ID}=8$

Greenberger, 2021

10881445

$85 \quad 119$

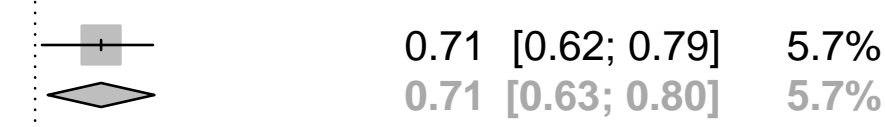

Prediction interval

$\mathrm{ID}=10$

lacano, 2021

andom effects mode
ediction interval

ID $=19$

Random effects mode

Prediction interval

ID $=20$
Thakkar, 2021

Thankar, 2021

Prediction interval

ID $=31$

Benjamini, 2021

cts mode

Prediction interval

$\mathrm{D}=32$

Del Poeta, 2021

Random effects mode

Prediction inter

$\mathrm{D}=37$

Random effects mode

Prediction interval

ID $=38$

Tadmor, 2021

Random effects mode

Prediction interval

$34 \quad 54$
$\quad 54$

$\begin{array}{lll}\square & 0.63[0.49 ; 0.76] & 5.1 \% \\ & 0.63[0.50 ; 0.76] & 5.1 \%\end{array}$

$0.75[0.73 ; 0.77] \quad 6.1 \%$

$4 \quad 10$

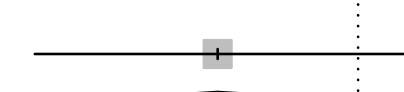

$0.40[0.12 ; 0.74] \quad 2.9 \%$

$64 \quad 102$

\begin{tabular}{lll}
$-0.63[0.53 ; 0.72]$ & $5.5 \%$ \\
\hdashline & $0.63[0.53 ; 0.72]$ & $5.5 \%$
\end{tabular}

ID $=40$

Gurion, 2021

$56 \quad 66$

$\stackrel{+}{\longrightarrow} \quad 0.85[0.74 ; 0.92] \quad 5.6 \%$

effects mode

$160 \quad 373$

$+$

$0.43[0.38 ; 0.48] \quad 6.0 \%$

$25 \quad 46 \quad+1$

$\begin{array}{ll}0.54[0.39 ; 0.69] & 4.9 \% \\ 0.54[0.40 ; 0.69] & 4.9 \%\end{array}$

in

$\begin{array}{llll}23 & 44 & 0.52[0.37 ; 0.68] & 4.9 \% \\ & 44 & 0.52[0.38 ; 0.67] & 4.9 \%\end{array}$

$\begin{array}{llll}49 & 84 & 0.58[0.47 ; 0.69] & 5.4 \% \\ 84 & 0.58[0.48 ; 0.69] & 5.4 \%\end{array}$

$\begin{array}{llll}49 \quad 84 & 0.58[0.47 ; 0.69] & 5.4 \% \\ 84 & 0.58[0.48 ; 0.69] & 5.4 \%\end{array}$

$83162 \quad 0.51[0.43 ; 0.59] \quad 5.7 \%$

$0.51[0.44 ; 0.59] \quad 5.7 \%$

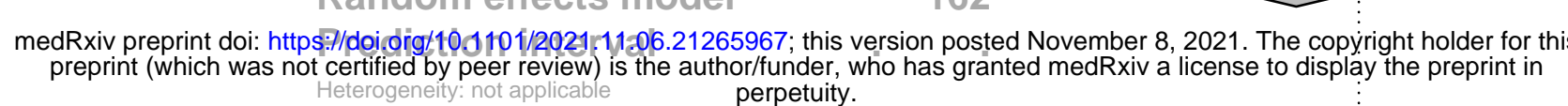

$\mathrm{D}=46$
Ram, 2021

Random effects mode

$47 \quad 63$

$\begin{array}{ll}0.75[0.62 ; 0.85] & 5.4 \% \\ 0.75[0.64 ; 0.85] & 5.4 \%\end{array}$

Prediction interval

ID $=47$

Ram, 2021

Random effects model

Prediction interval

$5 \quad 14$

(4)

$\begin{array}{lll}0.36[0.13 ; 0.65] & 3.5 \% \\ 0.36[0.11 ; 0.61] & 3.5 \%\end{array}$

$\mathrm{ID}=48$

Dhakal, 2021

Random effects mode

Prediction interval

$\mathrm{ID}=49$

Dhakal, 2021

Random effects mod

Prediction interval

$\mathrm{ID}=50$

Dhakal, 2021

Prediction interval

ID $=51$

Caocci, 2021

effects mode

Prediction interval

$\mathrm{ID}=57$

Pimpinelli, $2021-2$

Random effects model

Prediction interval

49

Random effects mode

Prediction ins

$0.69[0.58 ; 0.80] \quad 5.4 \%$

$27 \quad 45 \quad+\frac{1}{4}$

$0.60[0.46 ; 0.74] \quad 4.9 \%$

$0.21[0.05 ; 0.51] \quad 3.9 \%$

$3 \quad 14 \div \frac{1}{1}$

$0.21[0.00 ; 0.43] \quad 3.9 \%$

2863

$13 \quad 20$

\begin{tabular}{lll}
$0.65[0.41 ; 0.85]$ & $4.0 \%$ \\
\hline & $0.65[0.44 ; 0.86]$ & $4.0 \%$
\end{tabular}

$36 \quad 42$

\begin{tabular}{l|lll}
42 & + & $0.86[0.71 ; 0.95]$ & $5.4 \%$ \\
42 & + & $0.86[0.75 ; 0.96]$ & $5.4 \%$
\end{tabular}

$0.61[0.54 ; 0.69] 100.0 \%$

$[0.30 ; 0.93]$

$\begin{array}{llll}0.2 & 0.4 & 0.6 & 0.8\end{array}$ 
ID $=1$

Addeo, 2021

Random effects model

Prediction interval

Heterogeneity: not applicable

IID $=4$

Benda, 2021

Random effects model

Prediction interval

Heterogeneity: not applicable

ID $=12$

Maneikis, 2021

Random effects model

Prediction interval

Heterogeneity: not applicable

ID $=16$

Ollila, 2021

Random effects model

18

25

25

Prediction interval

$481 \quad 857$ 857

$53 \quad 123$

123
123

63160

160

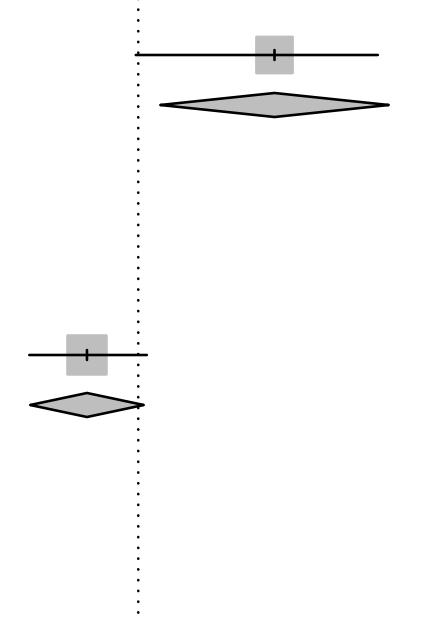

$+$

$\diamond$

$0.72[0.51 ; 0.88] \quad 7.6 \%$

$0.72[0.54 ; 0.90] \quad 7.6 \%$

$0.43[0.34 ; 0.52] \quad 8.8 \%$ $0.43[0.34 ; 0.52] \quad 8.8 \%$

$0.56[0.53 ; 0.59] \quad 9.3 \%$ $0.56[0.53 ; 0.59] \quad 9.3 \%$

$0.39[0.32 ; 0.47] \quad 9.0 \%$ $0.39[0.32 ; 0.47] \quad 9.0 \%$

$0.56[0.45 ; 0.66] \quad 8.7 \%$ $0.56[0.46 ; 0.66] \quad 8.7 \%$ $/ /$ doi.org/10.1101/2021.11.06.21265967; this version posted November 8,2021 . The copyright holder for this
certified by peer review) is the author/funder, who has granted medRxiv a license to display the preprint in
perpetuity Random effects model 93

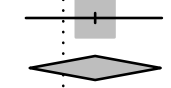

Prediction interval

Heterogeneity: not applicable

ID $=23$

Ghandili, 2021

Random effects model

Prediction interval

Heterogeneity: not applic

ID $=24$

Ramasamy, 2021

Random effects model

Prediction interval

Heterogeneity: not applicable

ID = 25

Stampfer, 2021

Random effects model

Prediction interval

Heterogeneity: not a ppic

ID $=44$

Easdale, 2021

Random effects model

Prediction interval

Heterogeneity: not applicable

ID $=54$

Harrington, 2021 -1

Random effects model

Prediction interval

Heterogeneity: not applicable

ID $=55$

Harrington, 2021 -2

Random effects model

Prediction interval

Heterogeneity: not applicable

ID $=56$

Pimpinelli, 2021 -2

Random effects model

Prediction interval

Heterogen

Random effects model Prediction interval Heterogeneity: $I^{2}=92 \%, \tau^{2}=0.0350, p<0.01$

Test for subgroup differences: $\chi_{11}^{2}=135.64, \mathrm{df}=11(p<0.01)$

$17 \quad 28$
$\quad 28$

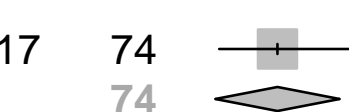

20

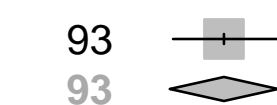

$21 \quad 55$

55
55
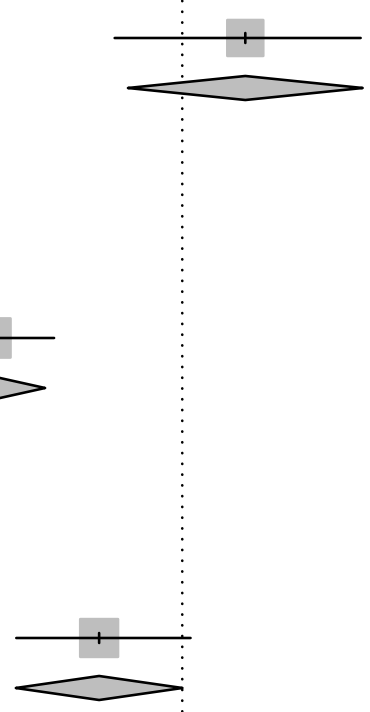

$14 \quad 16$

16

$15 \quad 21$
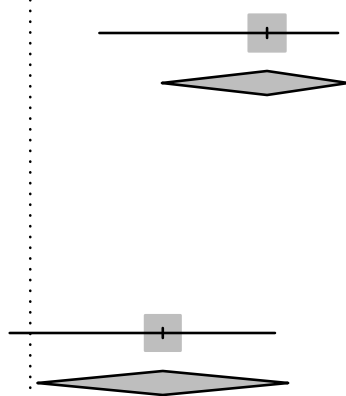

$0.88 \quad[0.62 ; 0.98] \quad 7.8 \%$

$0.88[0.71 ; 1.00] \quad 7.8 \%$

$0.38[0.25 ; 0.52] \quad 8.3 \%$

$0.38[0.25 ; 0.51] \quad 8.3 \%$

$0.61[0.41 ; 0.78] \quad 7.5 \%$

$0.61[0.43 ; 0.79] \quad 7.5 \%$

$0.22[0.14 ; 0.31] \quad 8.9 \%$

$0.22[0.13 ; 0.30] \quad 8.9 \%$

$--$

$0.23[0.14 ; 0.34] \quad 8.8 \%$
$0.23[0.13 ; 0.33]$
$8.8 \%$

$--$

